\title{
PROBLEM AUTORSTWA LISTU DO HEBRAJCZYKÓW
}

List do Hebrajczyków - prawdziwa perła nowotestamentalnej literatury - stale jest przedmiotem wielu badań i kontrowersji. Pomijamy problem kanoniczności tego Listu, także kwestionowanej, który stosunkowo wcześnie został definitywnie rozwiązany. Chrześcijanie przyjęli ten List za natchniony i przypisali św. Pawłowi, włączając go do tak zwanego Corpus Paulinum. A jednak od początku Pawłowe autorstwo nie tylko było kwestionowane, ale wprost zaprzeczane. Swiadomość nie-Pawłowej ręki, która skreśliła List, nie wykluczała łączenia go z autorytetem Apostoła Narodów i przekazywaniem go w tradycji jako Listu Pawłowego. Charakterystyczne pod tym względem jest nauczanie kolejnych kierowników Szkoły Aleksandryjskiej, Klemensa i Orygenesa, przekazane nam w dziele Euzebiuszowym.

Szkoła katechetyczna w Aleksandrii na przełomie drugiego i trzeciego wieku po Chrystusie wydała wielkich mężów, jakimi byli Klemens Aleksandryjski (150-215) i Orygenes (185-253). Ich świadectwa o autorstwie Listu do Hebrajczyków są ważne także z tego względu, że są to przedstawiciele Aleksandrii, która według niektórych, jak będziemy o tym jeszcze mówić, miałaby być związana z Listem do Hebrajczyków przez jej rzekomego autora, Apollosa z Aleksandrii. Aleksandryjczycy nic o takiej możliwości nie wspominają, natomiast są pierwszymi, którzy problem autorstwa podejmują i wskazują na innych autorów, nie św. Pawła, choć całkowicie Listu mu nie odbierają. Klemens stwierdza, że List do Hebrajczyków napisał Paweł w hebrajskim języku, Łukasz zaś troskliwie go przełożył i wydał dla Greków. Przy tej okazji zostało również podkreślone, że List do Hebrajczyków ma ten sam koloryt, jaki znajduje się w Dziejach Apostolskich ${ }^{1}$. Następca natomiast Klemensa, Orygenes podkreśla nie-Pawłowy styl Listu, przyznając, że zawiera on Pawłowe myśli spisane przez Klemensa Rzymskiego lub Łukasza. Orygenes również uważa, że jeżeli jakiś kościół przyjmuje List za Pawłowy, należy mu się za to uznanie, nie bez powodu bowiem starsi przekazali to dzieło jako Pawłowe ${ }^{2}$. Od tamtych zatem czasów, nie kwestionując kanoniczności i autorytetu Listu, poszukiwano ręki, która uwieczniła myśli Pawła.

1 Por. Euzebiusz z Cezarei, Historia Ecclesiastica, 6, 14, 2-4.

2 Por. tamże, s. $6,24,11-14$ 
W tym punkcie naszych rozważań nie zamierzamy w sposób systematyczny i wyczerpujący przedstawiać proponowanych na przestrzeni wieków rozwiązań problemu autorstwa Listu do Hebrajczyków. Zagadnienie to poruszają liczne komentarze, omawiają również specjalne artykuły J. Frankowskiego ${ }^{3}$. Wypada jedynie zwrócić uwagę na niektóre aspekty poruszonej w nagłówku problematyki. Historia egzegezy zna wiele osób, którym próbowano przypisać List do Hebrajczyków, zna również tyle samo kontrargumentów, które każdej z tych osób odmawiają autorstwa Listu. Sama ilość i różnorodność proponowanych rozwiązań świadczy o trudności problemu i hipotetyczności każdej propozycji jego rozwiązania. Nie ma łatwo dostępnych i przekonywających dowodów, które potrafiłyby położyć kres dyskusjom i przeważyć ich szalę na jedną stronę. To samo już na początku trzeba powiedzieć o podjętej obecnie próbie. Autor jej zdaje sobie sprawę z takiego właśnie stanu rzeczy i nie rości sobie pretensji do jego zmiany. Podjęcie zaś tej problematyki i zaproponowanie jej rozwiązania zostanie uzasadnione po dalszych jeszcze uwagach na temat poprzednich hipotez.

Ponieważ hipotez tych postawiono już wiele i każdej próbowano również wykazać, braki, stąd wielu, nie wdając się $\mathrm{w}$ przypuszczenia i polemiki, mówi o Autorze Listu jako o kimś, kto z woli Opatrzności pozostał i ma pozostać anonimowy. Pogodziliśmy się z faktem, że Listu nie napisał św. Paweł i dziś chyba już nikomu to nie przeszkadza w uznawaniu samego Listu za słowo Boże. Liturgia zrezygnowała $\mathrm{z}$ wymieniania imienia św. Pawła przy zapowiadaniu lektury Pisma do Hebrajczyków, a mówiąc - Corpus Paulinum pomija się ten List, omawiając go odrębnie. Natura jednak nie znosi próżni. Dlatego współczesna egzegeza preferuje także swoje rozwiązanie, na które wielu zgadza się choćby milcząco. Kandydatem na autora Listu do Hebrajczyków, dziś prawie powszechnie uznanym, jest Apollos z Aleksandrii. Uzasadnienie tej hipotezy szeroko przedstawione jest przez C. Spicqa ${ }^{4}$, którego argumenty przytacza S. Each ${ }^{5}$, a specjalnie uzasadnia H. W. Montefiore ${ }^{6}$. Sama hipoteza pochodzi od Marcina Lutra, który postawił ją w roku $1537^{7}$. Nie będziemy tu przytaczać argumentów, które zostały wysunięte na poparcie omawianej hipo-

${ }^{3}$ Problem autorstwa Listu do Hebrajczyków i etapy egzegezy katolickiej $w$ dobie wspótczesnej, „Stud. Theol. Vars. 6 (1958) 2, s. 201-233; Problem autorstwa Listu do Hebrajczyków" $i$ etapy egzegezy katolickiej $w$ dobie współczesnej (zmiana stanowiska), Stud. Theol. Vars. 7 (1969) 1, 3-33.

${ }^{4}$ Por. L'Epitre aux Hébraux (Etudes Bibliques), Paris 1952, 1, s. 211-217.

5 Por. List do Hebrajczyków, Poznań 1959, s. 57n.

6 Por. A Commentary on the Epistle to the Hebrews (Black's New Testament Commentaries) London 1969 , s. 9n.

7 Par. H. W. Montefiore, A Commentary..., j.w., s. 9. 
tezy. Starają się one uwzględnić specyficzne właściwości Listu do Hebrajczyków i ukazać ich przyczynę. Apollos znany jest nam na podstawie Dziejów Apostolskich (18,24 - 19,1) i Pierwszego Listu do Koryntian (3,44,6). W argumentach za Apollosowym autorstwem wykorzystuje się podaną w tych pismach Nowego Testamentu charakterystykę Apollosa, którą przekazuje nam przede wszystkim św. Łukasz w Dziejach Apostolskich. Pierwszy List do Koryntian świadczy o dużym autorytecie Apollosa, którego wymienia na równi z Piotrem i Pawłem. Czy to wszystko jest wystarczającym argumentem? Wydaje się, że nie, jeżeli C. Spicq po wyliczeniu dziesięciu rzeczowych argumentów swą listę kończy apodyktycznym stwierdzeniem, że jeżeli Listu nie napisał Apollos, to nie znamy i nie będziemy znać autora. Wobec takiego, jakby rozpaczliwego stwierdzenia, rzeczywiście Apollos jest kandydatem nie do odrzucenia i właściwie można było zrezygnować z poprzednich argumentów. Czy zaś faktycznie hipoteza ta jest ostatnią deską ratunku, pozostaje problemem otwartym. Odnośnie do argumentów za hipotezą o Apollosie, jako autorze Listu do Hebrajczyków, warto wskazać jeszcze na jedno niedopatrzenie. H. W. Montefiore omawiając sprawę autorstwa Listu porusza między innymi podaną przez Tertuliana hipotezę wskazującą na Barnabę jako na autora tego Listu. Koronnym kontrargumentem przeciw tej hipotezie jest to, że świadectwo Tertuliana jest stosunkowo późne, a jego hipoteza nie znana poprzednikom ${ }^{8}$. Kilka zaś stron dalej tenże sam autor podejmuje hipotezę Lutra i nie zauważa, że jest ona stosunkowo jeszcze późniejsza i tak samo nie znana poprzednikom. Rodzi się wątpliwość, czy aby powszechna zgoda na przyznanie Apollosowi autorstwa Listu do Hebrajczyków nie jest gestem sympatii dla jej wynalazcy i wyrazem swoiście pojętego ekumenizmu. W takim razie trzeba przypomnieć znane adagium: Amicus Plato, sed magis amica veritas!

Pozostawiając już omawianą hipotezę, stwierdzamy, że wysunięto różne rozwiązania i prawie wszystkie ważniejsze postacie pierwszego wieku zostały nimi objęte. Wymieniano Szczepana, Filipa, Piotra, Łukasza, Sylasa, Judę, Klemensa i innych. Ostatecznie problem mimo tak licznych prób jego rozwiązania pozostaje otwarty, a być może nigdy nie da się postawić zadowalającej wszystkich odpowiedzi.

Dlaczego jeszcze jedna próba?

Po takim stwierdzeniu należy uzasadnić ponowne podjęcie problematyki i wskazać na nowe podejście odnośnie do proponowanej hipotezy. Jest rzeczą znaną $w$ nauce, że zagadnienia nawet skazane na brak czy

\footnotetext{
${ }^{8}$ Por. tamże, s. 2.
} 
niemożliwość rozwiązania znajdują zawsze amatorów. Historia nauki potwierdza również fakt, że badania takich beznadziejnych dziedzin nie pozostają zupełnie bezpłodne. Chociaż bowiem głównie podjęty problem nie daje się zadowalająco, a czasem właściwie, rozwiązać, próby znalezienia tego niedostępnego rozwiązania owocują na innych płaszczyznach. Wiadomo, że perpetuum mobile, urządzenie, które wykonywałoby pracę nie pobierając energii, jest problemem skazanym na niepowodzenie. Próby jednak rozwiązania tego problemu nie ustają i chociaż nigdy nie doprowadziły i nie doprowadzą do pożądanego efektu, wyzwalają wiele pomysłowości, rodzą pasję poszukiwawczą i stały się w wielu wypadkach początkiem prawdziwego i naukowego zainteresowania fizyką. Innym przykładem jest znane twierdzenie Fermata, o którym orzeczono, że nie może być udowodnione, ale bardzo liczni, zwłaszcza początkujący matematycy, powracają do tego zagadnienia. Dzięki tym poszukiwaniom rozwinęła się cała teoria matematyczna zwana teorią liczb. Zasadniczy więc problem nie został rozwiązany, ale na jego marginesie uzyskano wiele istotnych odkryć. Można by na polu nauk humanistycznych wykazać wiele dziedzin, w których powracanie do tematów trudnych i zdaje się nierozwiązalnych przyczyniło się do postępu nauki. Trzeba jednak pamiętać, że nierozwiązalność problemów humanistycznych jest innego rodzaju niż w naukach przyrodniczych. Tu drążenie tego samego problemu, stawiającego zdecydowany opór nie jest sprawą tak beznadziejną jak w wypadkach wspomnianych wyżej. Przysłowiowa kropla może tu wydrążyć skałę. Taka sytuacja ogólnonaukowa jest usprawiedliwieniem nowego podjęcia problemu. Można się spodziewać, że podobne próby będą jeszcze niejednokrotnie podejmowane i chociaż nie osiągniemy absolutnej pewności na temat Autora Listu do Hebrajczyków, przy sposobności rozwiązywania tej zagadki dojdziemy do wielu pożytecznych wniosków.

Istnieje także uzasadnienie subiektywne, o którym w tym miejscu pozwolę sobie powiedzieć. Wśród tez do egzaminu doktorskiego miałem przygotować także problem autorstwa Listu do Hebrajczyków. Oczywiście problem został przedstawiony zgodnie z przyjętym stanem nauki, a więc ze wskazanie na Apollosa jako na najbardziej prawdopodobnego Autora Listu. To przedstawienie budziło jednak jakąś instynktowną niechẹc. Przedstawione argumenty nie były dla mnie przekonywające. Problem więc rodził sprzeciw i niepokój. Domagał się dalszego przemyślenia. W wyniku tego przemyślenia zrodziło się przekonanie, że uwzględniając istniejący tu margines niepewności, należy raczej w św. Łukaszu upatrywać autora Listu. Powrócenie do tej historycznie najstarszej hipotezy wydającej się także najbardziej prawdopodobną, związało się z licznymi próbami uzasadnienia tej hipotezy na podstawie badania samego Listu, jego treści i sposobów wyrazu. Próby te między innymi otworzyły drogę 
ku zastosowaniom lingwistyki matematycznej wspieranej obliczeniami komputerowymi. Tak powstał cały kompleks zagadnień. Na ile rzeczywiście rozwiązuje on zasadniczy problem, pozostanie jednak sprawą dyskusyjną.

Hipotetyczna geneza Listu

W hipotezach odnośnie do autorstwa Listu do Hebrajczyków można swobodnie przebierać i wybierać sobie najbardziej odpowiednią. Postawiono bowiem wiele tych hipotez i starano się dać im jakieś uzasadnienie. Nie chodzi więc o to, aby tylko opowiedzieć się za jedną z już istniejących hipotez. Wobec ich mnogości trudno byłoby chyba znaleźć jeszcze jednego kandydata na autora, który nie był dotychczas wymieniany i który z jakimś prawdopodobieństwem mógłby odpowiadać poszukiwaniom. Słuszne natomiast jest stwierdzenie, że nasi poprzednicy mogli lepiej się $w$ tej sprawie orientować. Nie chodzi także o tworzenie coraz bogatszej galerii domniemanych autorów.

Jeżeli hipoteza Apollosa wydała się niezadowalająca i mimo wszystko nie umotywowana należycie, trzeba rozpatrzeć inne, istniejące już hipotezy, a zwłaszcza chronologicznie wcześniejsze. Głównie jednak trzeba było dać przyjętej hipotezie nowe uzasadnienie, popatrzeć nieco inaczej na zagadnienie. Dlatego problem został postawiony nie od strony, kto mógłby być autorem lub na kogo wskazywała tradycja, ale zagadnienie ujęto od strony genetycznej, stawiając pytanie, dlaczego napisano ten List i dlaczego napisano go lub odebrano jako Pawłowy. W rozwiązaniu tego problemu musi pojawić się osoba Autora. Taki zatem przyjęto tok rozważania

\section{Zagadnienia szczegółowe}

Każda hipoteza o tyle jest pewniejsza, o ile więcej ma potwierdzeń. W rozważanym zagadnieniu, po przyjęciu Łukaszowego autorstwa Listu do Hebrajczyków, należało prześledzić treściowe powiązania między pismami przyjętymi bez zastrzeżeń jako Łukaszowe (Trzecia Ewangelia, Dzieje Apostolskie), a pismem hipotetycznym jakim jest List do Hebrajczyków. Pewne powiązania są powszechnie znane, inne wymagałyby rozważenia. Lista możliwych zagadnień i porównań jest bardzo obszerna. Autor rozprawy zajmował się niektórymi zagadnieniami i zostały one opracowane w osobnych publikacjach. Osiągnięte wyniki zostaną tu przytoczone. Szczególnie ważne wydaje się rozważenie roli Ducha Swiętego według Listu do Hebrajczyków. Jednym bowiem z argumentów przeciw 
hipotezie Łukaszowego autorstwa jest podkreślanie różnicy między pismami Łukaszowymi a Listem do Hebrajczyków polegającej na rzekomo nieproporcjonalnie znikomym uwzględnianiu roli Ducha Swiętego w Liście do Hebrajczyków na tle szczególnego podkreślenia tej roli w Trzeciej Ewangelii i Dziejach Apostolskich. Podjęte badania ${ }^{\circ}$ rzucają nowe i odmienne od szeroko lansowanego światło na ten problem.

Ponieważ innym kontrargumentem jest podkreślanie historycznego charakteru pism Łukaszowych i doktrynalno-teologicznego podejścia Listu do Hebrajczyków, ważne wydaje się ukazanie historiozbawczego myślenia Listu do Hebrajczyków i to wykazującego zależność literacką od Ewangelii Łukasza i Dziejów Apostolskich ${ }^{10}$. Historiozbawcze ujęcie uwzględniono w drobnym fragmencie Listu do Hebrajczyków. Szersze potraktowanie treści całego Listu pozwoliłoby na ukazanie, że Autor Listu myśli kategoriami historii zbawienia.

Wykazywanie pokrewieństw myślowych między Listem do Hebrajczyków a innymi pismami św. Łukasza jest prawdziwą kopalnią tematów. Nic więc dziwnego, że tylko niektóre zagadnienia będą wspomniane w ramach tej rozprawy.

\section{Powstanie Listu do Hebrajczyków}

Sprawę autorstwa Listu należy powiązać z rozważaniem jego genezy Tak specyficzne i doniosłe pismo Nowego Testamentu nie mogło pojawic się przypadkowo. Jest ono realizacją bardzo konkretnych i usystematyzowanych zamierzeń Autora, o czym świadczy między innymi ściśle uporządkowana struktura Listu ${ }^{11}$. W celu postawienia właściwych wniosków rozważymy kilka kolejnych punktów, które będą stanowić cegiełki w postawieniu ostatecznej hipotezy.

\section{Odpowiedzialność Pawła za śmierć Szczepana}

Szczepan i Szaweł, prześladowany i nawrócony prześladowca, dwie postacie pierwotnego chrześcijaństwa związały się ze sobą w świadomości wiernych dzięki relacji Dziejów Apostolskich, które wspominają raczej bierny udział Szawła w egzekucji Pierwszego Męczennika. Jest charakte-

- Por. T. Jelonek, Rola Ducha Swiętego wedtug Listu do Hebrajczyków, RuBib 34 (1981), s. 119-129.

${ }_{10}$ Por. T. J el o nek, Streszczenie dziet Łukaszowych w Liście do Hebrajczy$k o ́ w$, AnCrac 13 (1981), s. 143-151; T. J elonek, Poświadczające dzieła Boga wedtug $\mathrm{Hbr} 2,4$, RuBib 31 (1978), s. 16-22.

11 Por. A. Van ho y e, La structure littéraire de l'Épitre aux Hébreux (Studia Neo-Testamentica 1) Desclée 1963, passim; szczególnie: s. 59. 
rystyczne, że w Listach Pawłowych nie znajdujemy wzmianki o Szczepanie, o udziale Szawła w jego męczeństwie i o Pawłowym z tego powodu poczuciu winy czy odpowiedzialności, choć stwierdza Apostoł wy-

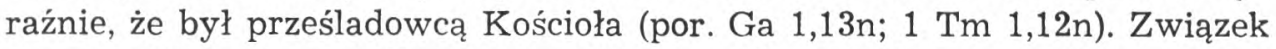
sprawy Szczepana z Szawłem jest więc daną Eukaszową, którą autor Dziejów Apostolskich szczególnie podkreśla, powracając do niej dwukrotnie. W opisie męczeństwa Szczepana czytamy o złożeniu szat u stóp Szawła $(7,58)$. Opis ten kończy się wzmianką, jakby wtrąconą, że Szaweł zgadzał się na zabicie go $(8,1)$. Umieszczenie tej wzmianki świadczy o tym, że Łukaszowi szczególnie zależało na podkreśleniu udziału i odpowiedzialności Pawła w tym, co się dokonało. Do sprawy tej powraca autor Dziejów Apostolskich przy opisie zajść w Jerozolimie, w wyniku których Paweł został uwięziony. Gdy pozwolono mu przemówić do ludu, Paweł opisał swoją drogą duchową, która prowadziła od prześladowania chrześcijan do głoszenia Chrystusa. W czasie tej mowy Paweł stwierdza: ,a kiedy przelewano krew Szczepana, Twego świadka, byłem przy tym i zgadzałem się, i pilnowałem szat jego zabójców” $(22,20)$. Na związek obu miejsc Dziejów Apostolskich, które wyraźnie podkreślają odpowiedzialność Pawła za zabicie Szczepana, wskazują paralele słowne, występujące w najbliższych kontekstach oraz znamienny paralelizm sytuacyjny, który wiąże los Pawła z losem Szczepana, choć los Pawła nie ma tak tragicznego finału. Po słowach bowiem wspominających Szczepana Żydzi uczynili Pawłowi podobnie, jak kiedyś postąpiono ze Szczepanem. Wśród krzyku rzucono się na niego. Jedynie żołnierze rzymscy ocalili go od śmierci. Do paralel słownych należy przede wszystkim stwierdzenie o zgodzie na zabicie. W obu kontekstach występuje określenie Chrystusa jako Sprawiedliwego $(7,52 ; 22,14)$, które oprócz tych dwu miejsc znajduje się jeszcze tylko raz w Dziejach Apostolskich $(3,14)$. Związek obu miejsc podkreślać mogą także wzmianki o wizjach, choć nie są one określone tymi samymi terminami. Szczepan ujrzał chwałę Bożą i Jezusa po prawicy Boga $(7,56)$, Paweł natomiast wspomina o zachwyceniu, jakiego doznał w świątyni jerozolimskiej $(22,17)$.

W świetle zatem Dziejów Apostolskich odpowiedzialność Pawła za śmierć Szczepana jest wyraźną daną Łukaszową. Można postawić pytanie, skąd pochodzi Łukaszowe przekonanie o odpowiedzialności Pawła za śmierć Szczepana. Czy jest to relacja dotycząca świadomości nurtującej Apostoła Narodów, której nie wyraził wprawdzie w swych Listach, ale zawarł $\mathrm{w}$ mowie jerozolimskiej, czy sformułowanie tej myśli jest dziełem samego Łukasza. Wychodząc $\mathrm{z}$ mowy zawartej $\mathrm{w}$ dwudziestym drugim rozdziale Dziejów Apostolskich należy opowiedzieć się za pierwszą z możliwości. Łukasz w mowach, które umieszcza w Dziejach Apostolskich oczywiście nie podaje dosłownego brzmienia wypowiedzianych $\mathrm{w}$ danych 
okolicznościach słów. W mistrzowski natomiast sposób każda z mów Dziejów charakteryzuje mówiącego i te myśli, które są dla niego właściwé. Mowa do Żydów, wypowiedziana przy pojmaniu Pawła, jest jedną z nielicznych znanych nam jego wypowiedzi skierowanych do społeczności żydowskiej. Cała korespondencja bowiem odnosi się do kościołów, które w swej większości składały się z nawróconych pogan. Nic więc dziwnego, że zredagowana przez Łukasza mowa zawiera to, co Paweł miał do powiedzenia Żydom, a nie musiał mówić poganom. Łukasz, który tak wiele czasu przebywał z Pawłem, znał jego myśli i uczucia. Wiedział, co nurtowało Pawłowa świadomość i jakie miał poczucie odpowiedzialności. Redagując mowę z dwudziestego drugiego rozdziału Dziejów Apostolskich, przedstawił sylwetkę duchową Apostoła, jak w danej sytuacji musiała się objawić. W niej znajdowało się miejsce na poczucie odpowiedzialności za śmierć Szczepana, które tym bardziej żywo musiało się narzucać w Jerozolimie i w sytuacji Pawła tak zbliżonej do tego, co przydarzyło się Szczepanowi. Wprawdzie tylko Eukasz informuje nas o tej świadomości Pawła, ale można stwierdzić, że oddaje tu stan duchowy Apostoła. Paweł był świadomy, że odpowiada za śmierć Szczepana, a Łukasz jest świadkiem tej świadomości.

\section{Pawet odpowiedzialny za niedokończone stowo}

Mowa Szczepana w relacji Łukaszowych Dziejów Apostolskich odgrywa szczególną rolę. Jest ona najdłuższą mową spośród wszystkich mów zapisanych w Dziejach Apostolskich. Wykazano rolę, jaką mowa Szczepana odgrywa w odczytaniu typologii Mojżesz - Chrystus, która przenika zarówno Trzecią Ewangelię, jak i Dzieje Apostolskie ${ }^{12}$. Nie jest więc mowa Szczepana jakimś epizodycznym fragmentem dzieła, ale została w nie kunsztownie wprawiona i powiązana z całością.

Szczepan swojej mowy nie dokończył. Kiedy po dłuższym wywodzie historycznym przeszedł do sprawy Jezusa i zwrócił się przeciw oskarżycielom z zarzutem zamordowania Sprawiedliwego i nieprzestrzegania Prawa, został umęczony. Jego mowa jest urwana, niedokończona. Można więc $\mathrm{w}$ oparciu o poprzednio ukazaną Pawłową odpowiedzialność za śmierć Szczepana mówić także o jego odpowiedzialności za niedokończone słowo. To słowo powinno być dokończone w myśl stwierdzenia, które znajdujemy w Liście do Hebrajczyków, że sprawiedliwy mówi także po śmierci $(11,4)$.

Sw. Paweł miał pełną świadomość swego powołania jako apostoł po-

12 Por. T. Jelonek, Typologia Mojżesz - Chrystus w dziełach św. Łukasza, AnCrac 8 (1976), s. $111-123$. 
gan (Ga 2,7), choć sprawa narodu izraelskiego jako narodu wybranego leżała mu bardzo na sercu (Rz 11). Nie podjął jednak Apostoł Narodów w jakiś pełniejszy sposób niedokończonego słowa, które Szczepan kierował do Żydów.

Sw. Łukasz w Dziejach Apostolskich zaznacza, że powołaniem Pawła było także zanieść świadectwo o Chrystusie do synów Izraela. Stwierdzenie takie znajduje się $\mathrm{w}$ słowach Chrystusa skierowanych do Ananiasza, gdy został on posłany, aby otworzyć oczy Szawłowi: „Idź - powiedział mu Pan - bo wybrałem sobie tego człowieka za narzędzie. On zaniesie imię moje do pogan i królów, i do synów Izraela" $(9,15)$. Na pierwszym miejscu wymienieni są poganie, co w stosunku do Pawła jest oczywiste. Wymienieni są jednak także Izraelici, ale w dalszej kolejności, Nie odpowiada to opisanej w Dziejach Apostolskich działalności Pawła w czasie jego podróży misyjnych, gdyż wtedy w poszczególnych miejscowościach zwracał się najpierw do Żydów, a nie znajdując u nich posłuchu, przystępował do nawracania pogan, co ze względu na lepszy skutek stanowiło główny rys Pawłowego apostolstwa. Końcowe rozdziały Dziejów Apostolskich poświęcone opisowi pojmania i uwięzienia św. Pawła mówią - jego wypowiedziach skierowanych do Żydów. W pewnym sensie konstrukcja Dziejów Apostolskich odpowiada więc programowi zarysowanemu wobec Ananiasza, ale nie czyni tego w pełni. Słowo Pawła bowiem nie odnosi skutku, a on sam musi korzystać z uprawnień obywatela rzymskiego, aby uniknąć zamachu na swoje życie.

Z Dziejów Apostolskich możemy więc wywnioskować, że Paweł świadomy swej odpowiedzialności za śmierć Szczepana odpowiedzialny był tym samym za niedokończone słowo Pierwszego Męczennika. Dzieje Apostolskie przekonują nas także, że powołaniem Pawła, Apostoła pogan, było również zaniesienie imienia Chrystusowego Izraelitom. Tę informację podaje nam św. Łukasz, podobnie jak już wyżej stwierdziliśmy, na podstawie świadomości swego mistrza i przyjaciela, którego tak dobrze znał i którego wspaniały portret ukazuje nam w swoim dziele. Wydaje się, że dotykamy tu problemów, które nurtowały Pawła, których jakimś śladem są wspomniane wyżej rozważania Listu do Rzymian. Równocześnie Apostoł Narodów w czasie swego życia nie podjął tego zadania, którego był świadomy. I to jakby niedokończenie Pawłowego dzieła dyskretnie, ale wyraźnie ukazuje nam św. Łukasz.

Puwet pisze do Żydów

Podkreśliliśmy już wyżej, że w Listach Pawłowych nie dochodzą do głosu sprawy, które z osobą Apostoła Narodów wiąże św. Łukasz. Mówiąc o Li- 
stach Pawłowych mieliśmy na myśli trzynaście pism kanonicznych, stanowiących łącznie z Listem do Hebrajczyków Corpus Paulinum. Z oczywistych względów nie uwzględnialiśmy Listu do Hebrajczyków. Czy jednak w ten sposób zostaje wyczerpana pisarska działalność św. Pawła? Nie rozważając odpowiedzi na to pytanie w całej rozciągłości, a ograniczając się do omawianego zagadnienia, można zapytać o nieznany, a hipotetyczny list skierowany do Żydów. $\mathrm{Na}$ to pytanie wielu egzegetów daje odpowiedź pozytywną, twierdząc, że Paweł pod koniec swego życia, w okresie poprzedzającym wypadki roku siedemdziesiątego, napisał List skierowany do chrześcijan pochodzenia żydowskiego i przebywających $\mathrm{w}$ Jerozolimie ${ }^{18}$. Pismo to musiało być napisane $\mathrm{w}$ języku hebrajskim Ten język był przecież Pawłowi dobrze znany, w nim przemawiał do swoich rodaków (Dz 21,40). W sytuacji walki podjętej w obronie tradycji narodowych list w innym języku, związanym $\mathrm{z}$ wrogą administracją i kulturą, był przez adresatów nie do przyjęcia. Paweł uważany był za zdrajcę. Czyż mógł, posługując się obcym językiem, umacniać to przekonanie, jeżeli chciał, aby jego list został w ogóle odczytany przez adresatów? Hebrajskie pismo Pawłowe nie zachowało się w swej pierwotnej postaci. Prawdopodobnie było to krótkie pismo, a jego treścią była przede wszystkim zachęta do wytrwania w obliczu zagrożeń. Hipotetyczne to pismo oczywiście nie zadośćuczyniło ani odpowiedzialności za niedokończone słowo Szczepana, ani nie było wypełnieniem posłannictwa zaniesienia imienia Chrystusa do Zyydów. W pewnym jednak sensie nawiązywało do obu tych spraw i stało się odskocznią do dalszego ich kontynuowania, ale juz przez św. Łukasza.

Istnieje bowiem bardzo prawdopodobne przypuszczenie, że rozważany List skierowany do Żydów stanowi fragment obecnego Listu do Hebrajczyków. Śledząc wypowiedzi Ojców aleksandryjskich spotykamy się z opinią o przepracowaniu przez Łukasza pisma Pawłowego, które było krótkim słowem zachęty (por. Hbr 13,22). Jest to ciekawa hipoteza, która łączy obecny List do Hebrajczyków z osobą samego Pawła. Tłumaczy ona odmienny charakter pewnych fragmentów Listu, które w odróżnieniu od doktrynalnego wykładu całości mają wybitnie epistolarny charakter. Takim fragmentem jest zakończenie Listu (13,18-25). Byłoby ambitnym przedsięwzięciem podjąc próbę odnalezienia i wydzielenia tej pierwotnej warstwy, na podstawie której skomponowano kanoniczny List do Hebrajczyków. Próba ta jednak przekracza ramy obecnej pracy.

Tymczasem zajmiemy się Listem do Hebrajczyków w jego ostatecznej formie, a więc opracowanym jako całość i w tej całości będziemy

13 Por. E. Dąbrowski, Język pierwotny Listu do Hebrajczyków, At. Kapł. 51 (1949), s. $34-44$. 
starali się odnaleźć niedokończone i domagające się dokończenia słowo Szczepana.

\section{Prolog Listu do Hebrajczyków i epilog Mowy Szczepana}

Czytelnika Listu do Hebrajczyków uderza brak epistolarnego adresu, List bowiem nie rozpoczyna się zwyczajowym zaznaczeniem autora i adresatów, brak mu także pozdrowienia skierowanego do tych ostatnich. Autor Listu rozpoczyna go od doktrynalnego wykładu, który w pierwszych wierszach przybiera postać bogatego w swej treści prologu $(1,1-4)$. Komentatorzy zwracają uwagę na fakt, że prolog ten jest nie tylko wprowadzeniem $\mathrm{w}$ tematykę dzieła, ale $\mathrm{w}$ pewnym sensie streszczeniem całości ${ }^{14}$. Odwróciwszy rozumowanie można powiedzieć, że cały List jest rozwinięciem myśli wyrażonych w prologu. Można zatem postawić sobie pytanie, czy myśli te, a więc problematyka Listu, są zupełnie oryginalne na tle Nowego Testamentu, czy znajdują one w innym miejscu Nowego Testamentu punkt zaczepienia. Odpowiedź na to pytanie stwierdza, że prolog Listu do Hebrajczyków jest odpowiednikiem epilogu Mowy Szczepana. Tę odpowiedź będziemy starali się uzasadnić.

Przez epilog Mowy Szczepana będziemy rozumieć ostatnie jej sformułowania (Dz 7,51nn.56), gdyż, jak wiemy, mowa ta została przerwana, nie posiada więc formalnego zakończenia. Po dłuższym wywodzie historycznym, w którym Szczepan szczególnie podkreśla postacie Abrahama, Józefa i Mojżesza oraz fakt zbudowania domu dla Pana przez Salomona, przechodzi on do ostrych słów skierowanych przeciw oponentom: „Twardego karku i opornych serc i uszu! Wy zawsze sprzeciwiacie się Duchowi Świętemu. Jak ojcowie wasi, tak i wy! Któregoż z proroków nie prześladowali wasi ojcowie? Pozabijali nawet tych, którzy przepowiadali przyjście Sprawiedliwego. A wyście zdradzili Go teraz i zamordowali. Wy, którzyście otrzymali Prawo za pośrednictwem aniołów, lecz nie przestrzegaliście go" (7,51nn). Po tych słowach słuchacze unieśli się gniewem. Wtedy Szczepan napełniony został specjalnie Duchem Swiętym i otrzymał wizję nieba. Wpatrzony w nie rzekł: ,Widzę niebo otwarte i Syna Człowieczego, stojącego po prawicy Boga" $(7,56)$. Te słowa stały się ostatecznym powodem ukamienowania.

Postaramy się rozważyć paralele, jakie istnieją między przytoczonymi siowami Szczepana a prologiem Listu do Hebrajczyków. W Mowie Szczepana znajdujemy przeciwstawienie ojców i pokolenia, do którego mówca przemawia. W prologu Listu do Hebrajczyków spotykamy podobne ze-

${ }_{14}$ Por. C. Spicq, L’Épitre aux Hébreux, j.w., (przyp. 4), 2, s. 1; S. Each, List do Hebrajczyków, jw. (przyp.5), s. 121. 
stawienie. W pierwszym wypadku mówca nie identyfikuje się z odbiorcami mówiąc „wy”, a w drugim Autor Listu zalicza się do współczesnego mu pokolenia, używając zaimka ,my” (w trzecim przypadku). Mamy zatem paralelne wyróżnienie członów:

$$
\begin{aligned}
& \text { pateres - hymeis }(\mathrm{MS})^{15} \\
& \text { patrasin - hèmin }(\mathrm{Hbr})
\end{aligned}
$$

Z tym zestawieniem łączy się następne, w którym w pierwszych członach powtarza się słowo ,prorocy”, a ich korelatyw określony jest raz jako Sprawiedliwy, drugi raz jako Syn, a w obu wypadkach chodzi o Jezusa.

$$
\begin{gathered}
\text { prophètōn - dikaiou (MS) } \\
\text { prophètais - hyiō (Hbr) }
\end{gathered}
$$

Zarówno ojcowie, jak oskarża Żydów Szczepan, jak i oni sami sa oporni na słowo Boże, ojcowie prześladowali proroków, współcześni Szczepanowi zamordowali Sprawiedliwego. Autor Listu do Hebrajczyków zestawia ojców i współczesne sobie pokolenie, ale zwraca się do chrześcijan, do których sam się zalicza. Istnieje także pewna ciągłość tych dwu pokoleń (poprzedniego i współczesnego), jest to ciągłość Bożego objawienia. Będąc ciagłe, w Synu uzyskuje ono jednak najwyższy stopień doskonałości.

Mamy zatem podobne $\mathrm{w}$ obu wypadkach wyróżnienie pokoleń i na nie wskazaliśmy jako na paralelę. List do Hebrajczyków podejmuje to wyróżnienie nadając mu nową treść. Jest bowiem dokończeniem Mowy Szczepana, a więc nie tylko dalszym ciągiem, ale rozwinięciem myśli, wskazuje nie na negatywną stronę zagadnienia, ale na pozytywną. Nie na opór względem Boga, lecz na rozwój i transpozycję Bożego objawienia. Szczepan wymienia proroków jako pierwszy etap objawienia, któremu się sprzeciwiano. W Liście do Hebrajczyków jest to także pierwszy etap jeszcze niepełnego objawienia. W Mowie Szczepana prorokom przeciwstawiony jest Jezus jako Sprawiedliwy, który kończy erę proroków, oni bowiem ku Niemu się kierowali, zapowiadając Jego przyjście. Spotkał Go podobny los, jaki spotykał proroków. W Liście do Hebrajczyków po etapie objawienia dokonanego $\mathrm{w}$ prorokach wymieniony jest etap objawienia Bożego w Synu. Podkreślona jest bardziej Jego transcendencja w stosunku do poprzednich Bożych wysłanników, jest jednak, podobnie jak w Mowie Szczepana, realizacją dalszego ciągu zbawczej ekonomii. Można zatem dostrzec w omawianych zestawach pierwsze podobieństwo epilogu Mowy Szczepana i prologu Listu do Hebrajczyków. Jest ono może bardziej formalno-stylistyczne, ale i pod względem treściowym istnieje tu pew-

15 MS tu i następnie jest skrótem oznaczającym „Mowa Szczepana”. 
ne pokrewieństwo. Trzeba pamiętać, że podjęcie Szczepanowego słowa w Liście do Hebrajczyków następuje w innej sytuacji mówiącego. Szczepan przemawiał do wrogów rodzącego się chrześcijaństwa, List do Hebrajczyków podejmuje jego niedokończone słowo, ale adresowany jest do chrześcijan, możliwe, że narażonych na niebezpieczeństwo błędów, które tak stanowczo zwalczał Szczepan.

Szczepan kończąc mowę stwierdza, że widzi otwarte niebo i Syna Człowieczego stojącego po prawicy Boga. W teologicznej wizji prologu Listu do Hebrajczyków po wspomnieniu godności Syna i Jego dzieła, Autor dochodzi do stwierdzenia, że zasiadł On po prawicy Majestatu. Możemy w tym stwierdzeniu zobaczyć następną, tym razem wyraźnie treściową paralelę między epilogiem Mowy Szczepana a prologiem Listu do Hebrajczyków.

Jeszcze jedną paralelą jest wzmianka o aniołach, która wystẹpuje w obu tekstach. Szczepan oskarża swych przeciwników, że nie przestrzegają Prawa, które otrzymali za pośrednictwem aniołów. Autor Listu do Hebrajczyków stwierdza, że Jezus stał się wyższym od aniołów. Myśl tę rozwinie w dalszym ciągu Listu, w naszym miejscu podkreślona jest już jednak pośrednicza rola aniołów w dziele objawienia, co wynika z kontekstu, gdyż drugi desygnat porównania, Jezus, przedstawiony jest jako pośrednik objawienia.

W prologu Listu do Hebrajczyków można zatem odnaleźć pokrewieństwa myślowe z epilogiem Mowy Szczepana. Są one poparciem tezy, że mamy tu do czynienia z kontynuacja przerwanego słowa. Łukasz, redaktor Mowy Szczepana, dyskretnie, ale wystarczająco wyraźnie wiąże jej koniec z początkiem Listu do Hebrajczyków. Istnieją także pomosty łączące omawiany epilog Mowy Szczepana z całością Listu do Hebrajczyków.

\section{Epilog Mowy Szczepana a treść Listu do Hebrajczyków}

Treści poruszone w epilogu Mowy Szczepana znajdują wyraźne odzwierciedlenie w Liście do Hebrajczyków. Szczepan mówi o sprzeciwianiu się Duchowi Świętemu, prześladowaniu proroków i otrzymaniu Prawa za pośrednictwem aniołów. List do Hebrajczyków podejmuje te wątki. Jest on wielkim wołaniem o wierność i w bardzo ostrych słowach przestrzega przed odstepstwem. Sprzeciw wobec Bożego planu zbawczego według myśli Autora Listu w specjalny sposób dotyka Ducha Świętego ${ }^{16}$. Chrześcijanie nie unikną kary i to większej niż kara za nieposłu-

16 Szerzej o pneumatologicznej myśli Listu do Hebrajczyków por. T. J e I o n e k, Rola Ducha Swiętego. jw. (przypis 9). 
szeństwo Izraela, jeżeli nie będą troszczyć się o zbawienie, które łączy się z udzielaniem Ducha Swiętego $(2,3 n){ }^{17}$. Duch Swięty ostrzega przed zatwardziałością serc podobną do zatwardziałości Izraelitów wędrujących przez pustynię $(3,7)$. Bardzo gwałtowne ostrzeżenie znajduje się w szóstym rozdziale Listu (6,4-6). Podkreśla ono, że chrześcijanin staje się uczestnikiem Ducha Świętego, odstępstwo zaś przekreśla samą istotę tego daru. Najwyraźniej stwierdza Autor Listu, że odstępstwo jest sprzeciwianiem się Duchowi Świętemu, gdy nazywa je obelżywością wobec Ducha Świętego $(10,29)$. List do Hebrajczyków nie na licznych miejscach wspomina Ducha Świętego. Jeżeli z siedmiu wypowiedzi o Duchu Świętym cztery wiążą się ze sprawą odstępstwa, to znaczy, że jest to temat wyraźnie podkreślony. Poruszane tu sprzeniewierzanie się Duchowi Swiętemu jest treściowym powiązaniem ze sformułowaniem użytym w epilogu Mowy Szczepana. Drugim elementem wspólnym dla epilogu Mowy Szczepana i Listu do Hebrajczyków jest wzmianka o prześladowaniu proroków. Szczepan zarzuca je przodkom swoich oskarżycieli, List do Hebrajczyków w rozdziale jedenastym, wymieniając w przeglądzie historycznym przykłady wiary, mówi o rozlicznych prześladowaniach proroków (11,33-38). W całym Nowym Testamencie tylko w trzech miejscach przytoczona jest judaistyczna nauka o aniołach jako pośrednikach w przekazaniu prawa Mojżeszowego. Wzmianki te spotykamy w Mowie Szczepana $(7,38.53)$ i w Liście do Hebrajczyków $(2,2)$. W wyliczeniu powiązań między epilogiem Mowy Szczepana a prologiem Listu do Hebrajczyków mówiliśmy o stwierdzeniu, że Jezus zasiadł po prawicy Boga. Szczepan widzi Go w niebie i oznajmia o tym swym prześladowcom. Stwierdzenie o zasiadaniu Jezusa po prawicy Ojca powtarza się w Liście do Hebrajczyków także w innych miejscach $(8,1 ; 10,12 ; 12,2)$, a List ten mówiąc, że Jezus jako arcykapłan ,,przeszedł przez niebiosa” (4,14) wyznacza kierunek swojej teologii. Jest to teologia wniebowstąpienia i kierunek $\mathrm{ku}$ niebu zachowuje w całej swej treści ${ }^{18}$.

Tak więc w epilogu Mowy Szczepana nie tylko można znaleźć punkty styczne z prologiem Listu do Hebrajczyków, ale poruszone w tym epilogu treści doskonale korespondują z danymi Listu do Hebrajczyków. Może to być następnym potwierdzeniem tego, że List do Hebrajczyków jest podjęciem niedokończonego słowa Szczepana. Myśli, które Szczepan wypowiedział na końcu swej mowy, znajdują odbicie w różnych miejscach Listu.

17 Por. T. Jelonek, Poświadczajace dzieła Boga..., s. 20.

18 Por. T. Jelonek, Obraz Syjonu $w$ Apokalipsie $i w$ Liście do Hebrajczyków, Studia Warmińskie, 12 (1975), s. 494. 
Inne podobieństwa między Mowa Szczepana a Listem do Hebrajczyków

Rozważyliśmy najpierw epilog Mowy Szczepana i podobieństwa, jakie istnieją między nim a Listem do Hebrajczyków. Wysuwając hipotezę, że List do Hebrajczyków jest podjęciem niedokończonego słowa Szczepana, zwróciliśmy uwagę na jego ostatnie wypowiedzi, które zostały brutalnie przerwane, a więc szczególnie wymagały dokończenia. Omawiane związki między epilogiem Mowy Szczepana a Listem do Hebrajczyków nie wyczerpują listy wszystkich powiązań, które istnieją między Mową Szczepana jako całością a Listem. Do nich zatem obecnie przechodzimy.

Szczepan został oskarżony przez fałszywych świadków, którzy stwierdzili: „słyszeliśmy, jak mówił, że Jezus Nazarejczyk zburzy to miejsce i pozmienia zwyczaje, które nam Mojżesz przekazał" (Dz 6,14). Oskarżenie dotyczy świątyni i prawa Mojżeszowego. Stąd głównym przedmiotem Mowy Szczepana, jako obrony wobec zarzutów, jest Mojżesz i jego dzieło oraz znak przybytku ${ }^{19}$. Te same tematy odnajdujemy w Liście do Hebrajczyków. Podobnie jak Mowa Szczepana List do Hebrajczyków opisuje obszernie dzieje Mojżesza (11,23-29). Jest charakterystyczne, że jedynie te dwa opisy stosują dla określenia urody małego Mojżesza termin asteios (Dz 7,20; Hbr 11,23), nie występujący poza tym w Nowym Testamencie. Jest on w obu wypadkach przeniesiony z greckiego tekstu Starego Testamentu (LXX), gdzie występuje w opisie dzieciństwa Mojżesza (Wj 2,2).

Typologia Mojżesz - Chrystus, która w Mowie Szczepana jest zarysowana, w Liście do Hebrajczyków występuje w bardzo dojrzałej formie ${ }^{20}$. Szczepan zajmuje się postacią Mojżesza, aby przekonać swych adwersarzy, że Jezus nie sprzeciwia się zwyczajom nadanym Izraelitom przez Mojżesza. Jezus nie sprzeciwia się, ale Jego nauka zwyczaje te przerasta, jak postać Jezusa nie przekreśla postaci Mojżesza, ale Jezus jest od Mojżesza wyższy. Tezę tę, która w Mowie Szczepana nie jest wyrażona expressis verbis, bardzo wyraźnie ukazuje cała Łukaszowa typologia Mojżesz - Chrystus, która, jak wykazaliśmy w cytowanym wyżej artykule, przenika całe dzieło Łukasza (Trzecia Ewangelia i Dzieje Apostolskie). Dla odczytania tej typologii zasadnicze znaczenie ma Mowa Szczepana. Jeżeli typologia ta nie była czytelna dla słuchaczy Szczepana, przyjęli bowiem spokojnie całą historię Mojżesza, a zareagowali dopiero na wzmiankę o zamordowaniu Sprawiedliwego, to jednak jest ona $\mathrm{z}$ pewnością świadomie podkreślona przez Łukasza jako redaktora Mowy. Mowa

19 Por. A. Wikenhauser, Die Apostolgeschichte (Regensburger Neues Testament) Regensburg ${ }^{3}$ 1956, s. 87. s. 123

${ }^{20}$ Por. T. Jelonek, Typologia Mojżesz - Chrystus w dziełach św. Łukasza, 17 - Analecta Cracoviensia 
ta odgrywa zasadniczą rolę w konstrukcji Łukaszowej typologii Mojżesz Chrystus, a więc główna teza, której typologia ta służy, wypływa jakby naturalnie z Mowy Szczepana jako ze swego źródła. I właśnie ta teza zostaje później w sposób dojrzały rozwinięta w typologii Mojżesz - Chryștus Listu do Hebrajczyków zwłaszcza w rozdziale trzecim $(3,1-6)$ oraz w głównym przeciwstawieniu dotyczącym starego i nowego przymierza w rozdziale dwunastym $(12,18-24)$. To, co odnosi się do Jezusa, a przede wszystkim jego postać, nie jest przekreśleniem wartości Starego Testamentu, ale je nieskończenie przerasta tak, że stają się one jedynie cieniem prawdziwej rzeczywistości. Jezus nie przekreśla Mojżesza, ale „o tyle nawet większej czci godzien jest od Mojżesza, o ile większą cześć od domu ma jego budowniczy" (3,3). W zestawieniu zatem Jezusa i Mojżesza możemy znów List do Hebrajczyków uważać za kontynuację, dokończenie Mowy Szczepana. Oczywiście zawiera on naukę bardziej rozwiniętą, a rozwinięcie to idzie po linii przyjętej w Mowie Szczepana przez Łukasza, chociaż ona w samej mowie nie jest wyraźnie naznaczona. Byłby to jeszcze jeden argument za Łukaszowym rozwinięciem Mowy Szczepana w Liście do Hebrajczyków.

Jezus nie przekreśla Mojżesza, Jego prawo nie przekreśla prawa Mojżeszowego. Szczepan nazywa je „słowami życia” (7,38). Mojżesz otrzymał słowa życia, aby przekazać je ludowi. W tym określeniu przejawia się pozytywny stosunek Szczepana do prawa nadanego przez Mojżesza. Określenie to kontrastuje $\mathrm{z}$ wieloma wypowiedziami św. Pawła, z których dla przykładu przytoczymy zamieszczoną w Drugim Liście do Koryntian, gdzie mówi o posługiwaniu śmierci utrwalonym literami w kamieniu $(3,7)$, nazywając dalej Prawo posługiwaniem potępieniu $(3,9)$. Szczepan mówi o słowach życia, znów nie przekreśla wartości starego przymierza, co oczywiście w kontekście celu mowy jako obrony na postawione zarzuty jest zupełnie zrozumiałe. W innym kontekście mówi św. Paweł i w całości wszystkie te wypowiedzi, pozornie sprzeczne, tworzą właściwą syntezę stosunku Starego i Nowego Testamentu. Pozytywne i dopatrujące się wartości podejście do Prawa Mojżeszowego znajdujemy również w Liście do Hebrajczyków. Wynika to najpierw z ogólnego nastawienia Listu, o którym wspominaliśmy wyżej, a które można sformułować następująco: Rzeczywistość, której uczestnikami są adresaci Listu, jest zawsze kontynuacją ekonomii Starego Testamentu i chociaż kontynuacja ta została tak ubogacona nową treścią, że można mówić o nowej ekonomii, której poprzednia była tylko cieniem, to jednak nie przekreśla zasadniczych wartości tego, co nigdy nie zostało zakwestionowane, a jest kontynuowane. Zasadniczo elementy ekonomii Starego Testamentu są pozytywne, a jeśli List mówi o ich brakach, to są to przede wszystkim braki względne $\mathrm{w}$ porównaniu $\mathrm{z}$ nowością Nowego Testamentu. Autor 
szczególnie podkreśla jedność ekonomii Bożej, która realizuje șie : w dwu etapach, Pierwszy był jeszcze w swych objawach niedoskonały, drugi zaś jest przebogaty ${ }^{21}$. Odnośnie do prawa Starego Testamentu w Liście do Hebrajczyków znajdujemy określenie, które ekwiwalentnie nazywa to prawo dobrą nowiną. Jeżeli adresaci także otrzymali dobrą nowinę, jak tamci, to znaczy jak Izraelici wędrujący pod wodzą Mojżesza $(4,2)$, to otrzymane przez nich prawo związane $\mathrm{z}$ obietnicami było dobrą nowiną. Jeżeli ona nie zaowocowała, nie jest to winą samego, pozytywnie pojmowanego prawa, ale okoliczności dla niego zewnętrznych. Słuchaczom brakło wiary $(4,2)$. W wypadku stosunku do Prawa Mojżeszowego możemy zatem dopatrzeć się wspólnego ujęcia w Mowie Szczepana i w Liście do Hebrajczyków, choć problem ten nie jest tak wyraźny, jak zagadnienie związane z samą postacią Mojżesza. Ostatecznie można problem Prawa traktować jako część tamtego zagadnienia, chodzi bowiem o ,zwyczaje, które Mojżesz. przekazał" (Dz 6,14).

Problem miejsca świętego

O wiele szerszy jest problem miejsca świętego, który w oskarżeniu przeciw Szczepanowi wysunięty został na pierwsze miejsce. W Liście do Hebrajczyków przybytek i kult Starego Testamentu jako cienie rzeczywistości nowej potraktowane są bardzo szeroko. Już to samo stanowi dla nas argument dla przeprowadzonej tezy. Postaramy się jednak przypatrzeć dodatkowo pewnym aspektom tej sprawy.

Interesujący jest problem nazewnictwa. Miejsce święte w Nowym Testamencie oznaczane jest kilkoma terminami. Bardziej sprecyzowanymi terminami oznaczającymi przede wszystkim świątynię jerozolimską są to hieron i ho naos, oznaczeniem przybytku jest natomiast he skène. Jest charakterystyczne, że zarówno termin hieron jak i naos nie występuje w Mowie Szczepana i w Liście do Hebrajczyków, choć oba te terminy stosuje św. Łukasz w swej Ewangelii i w Dziejach Apostolskich poza mową Szczepana ${ }^{22}$.

W Trzeciej Ewangelii termin hieron występuje w następujących sytuacjach:

- Starzec Symeon udaje się do świątyni $(2,27)$.

- Anna prorokini nie rozstaje się ze świątynią $(2,37)$.

- Rodzice znajdują Jezusa w świątyni $(2,46)$.

21 Por. T. Jelonek, „Dotykalne” i "Góra Syjon”. Właściwa treść przeciwstawienia w $\mathrm{Hbr} 12,18-24$, AnCrac 9 (1977), s. 139-154.

${ }_{22}$ Por. J. H. M oulton, A. S. Geden, A concordance to the Greek New T'estament, Edinburgh ${ }^{4} 1963$, s. 472.661. 
- Diabeł stawia Jezusa na narożniku świątyni $(4,9)$.

- W przypowieści o faryzeuszu i celniku ci dwaj wchodzą do świątyni $(18,10)$.

- Jezus wszedł do świątyni i zaczął wyrzucać sprzedających $(19,45)$.

- Codziennie potem naucza w świątyni $(19,47)$.

- Pewnego dnia tam naucza $(20,1)$.

- Niektórzy mówią o świątyni, że jest przyozdobiona $(21,37)$.

- Rano lud spieszy do świątyni, aby Go słuchać $(21,38)$.

- Jezus przy pojmaniu zwraca się do dowódcy straży świątyni $(22,52)$.

- Stwierdza, że codziennie bywał w świątyni $(22,53)$.

- Uczniowie wróciwszy po wniebowstąpieniu do Jerozolimy stale przebywali w świątyni $(24,53)$.

Ten sam termin spotykamy w Dziejach Apostolskich:

- Uczniowie codziennie trwają w świątyni $(2,46)$.

- Piotr i Jan wchodzą do świątyni $(3,1)$.

- Przy bramie świątyni kładziono chromego $(3,2)$.

- Zobaczył on apostołów wchodzących do świątyni $(3,3)$.

- Uzdrowiony wszedł z nimi do świątyni $(3,8)$.

- Poznali, że to ten który siadał przy bramie świątyni $(3,10)$.

- Do przemawiających apostołów podszedł dowódca straży świątyni $(4,1)$.

- Anioł uwalniając apostołów z więzienia nakazuje im głosić w świątyni $(5,20)$.

- O świcie weszli do świątyni $(5,21)$.

- Dowódca straży świątyni nie może pojąć, co stało się z apostołami $(5,24)$.

- Ktoś oznajmia, że apostołowie są w świątyni $(5,25)$.

- Uczniowie nie przestali nauczać w świątyni $(5,42)$.

- Demetriusz w Efezie ostrzega przed niebezpieczeństwem, jakie grozi świątyni Artemidy (19,27).

- Paweł wszedł do świątyni dla oczyszczenia $(21,26)$.

- Żydzi zobaczyli go w świątyni $(21,27)$.

- Oskarżają, że do świątyni wprowadził poganina $(21,28)$.

- Sądzili, że wprowadził do świątyni $(21,29)$.

- Porwawszy Pawła wlekli poza świątynię $(21,30)$.

- Paweł mówi o modlitwie w świątyni $(22,17)$.

- Oskarżają Pawła o usiłowanie zbezczeszczenia świątyni (24,6).

- Paweł stwierdza, że nie spotkano go w świątyni rozprawiającego lub wywołującego zbiegowisko $(24,12)$.

- Spotkali go natomiast w świątyni oczyszczonego $(24,18)$.

- Paweł broni się, że nie wykroczył przeciw świątyni $(26,21)$. 
W pismach Łukaszowych spotykamy także termin naos, w Trzeciej Ewangelii znajduje on następujące zastosowania:

- Los wyznaczył Zachariaszowi wejście do przybytku $(1,9)$.

- Lud dziwi się, że Zachariasz długo przebywa w przybytku $(1,21)$.

- Po wyjściu zrozumieli, że miał widzenie w przybytku $(1,22)$.

- Zasłona przybytku rozdarła się przez środek $(23,45)$.

W Dziejach Apostolskich termin naos występuje tylko dwukrotnie:

- Paweł na Areopagu stwierdza, że Bóg nie mieszka w świątyniach zbudowanych ręką ludzką $(17,24)$.

- Demetriusz w Efezie wyrabiał srebrne świątyńki Artemidy $(19,24)$.

Interesujące terminy znajdujemy także w innych pismach Nowego Testamentu. Pierwszy $\mathrm{z}$ nich znajduje się przede wszystkim w Ewangeliach i występuje w nich następującą ilość razy ${ }^{23}$ :
w Ewangelii Mateuszowej
11 razy
w Ewangelii Markowej
9 razy
w Ewangelii Łukaszowej
14 razy
w Ewangelii Janowej
10 razy

Poza Ewangeliami przeglądnęliśmy występowanie tego terminu w Dziejach Apostolskich, a w pozostałych pismach znajdujemy go jedynie raz w Pierwszym Liście do Koryntian (9,13), gdzie występuje w stwierdzeniu, że ci, którzy trudzą się około ofiar, żywią się ze świątyni.

Jeżeli chodzi o termin naos, występuje on w większej ilości pism, choć sumarycznie w Nowym Testamencie jest używany rzadziej ${ }^{24}$. I tak:

$\begin{array}{ll}\text { Ewangelia Mateuszowa } & -9 \mathrm{razy} \\ \text { Ewangelia Markowa } & -3 \mathrm{razy} \\ \text { Ewangelia Eukaszowa } & -4 \mathrm{razy} \\ \text { Ewangelia Janowa } & -3 \mathrm{razy} \\ \text { Dzieje Apostolskie } & -2 \mathrm{razy} \\ \text { Pierwszy List do Koryntian } & -4 \mathrm{razy} \\ \text { Drugi List do Koryntian } & -2 \mathrm{razy} \\ \text { List do Efezjan } & -1 \mathrm{raz} \\ \text { Drugi List do Tesaloniczan } & -1 \mathrm{raz} \\ \text { Apokalipsa } & -16 \mathrm{razy}\end{array}$

Oba terminy w Ewangeliach zasadniczo oznaczają świątynię jerozolimską. Wydaje się, że hieron bardziej podkreśla jej stronę zewnętrzną,

${ }^{23}$ Por. R. Morgenthaler, Statistik des Neutestamentlichen Wortschatzes, Frankfurt am Main 1958, s. 106.

${ }^{24}$ Por. tamże, s. 122. 
a. więc miejsce kultu, budynek, drugi zaś termin określając tę samą rzeczywistość wskazuje na jej duchowe wartości. Mamy więc tu bardziej świątynię jako sanktuarium, niż zabudowanie. Jeśli nawet nie wszędzie dałoby się takie rozróżnienie utrzymać, jest ono z pewnością własnością Łukasza. Jeżeli ktoś wchodzi, przebywa na terenie świątyni, jest z nią związany, będzie użyty termin hieron. Jeżeli zaś chodzi o sprawę kultu, w tym miejscu wystąpi termin naos. Dlatego pierwszy z tych terminów w jednym wypadku nie oznacza świątyni jerozolimskiej, lecz efeską świątynię Artemidy. Drug̣i zaś termin w Dziejach Apostolskich oznacza ogólnie miejsce kultu oraz służące pogańskiemu kultowi talizmany w kształcie świątyniek Artemidy. Na tym tle warto zauważyć, że w Dziejach Apostolskich termin hieron odnosić się będzie również do świątyni rzekomo zbezczeszczonej przez Pawła przez wprowadzenie pogan na jej teren. Łukasz podkreśla w tym zarzucie jedynie aspekt terytorialny, a nie kultyczny. Ze względu na specyficzne przesunięcie znaczeniowe, które jest własnością nie tylko Łukasza, termin naos oznacza nie tylko świątynię jako budowlę, służącą kultowi, ale stosowany jest w znaczeniu metaforycznym, a również oznacza, szczególnie w Apokalipsie, świątynię w niebie (Apokalipsa nie zna terminu hieron). Do znaczenia metaforycznego zaliczamy określenie Ciała Jezusa jako świątyni (J 2,19-21), Pawłową naukę o Kościele jako rosnącej w Panu świątyni (Ef 2,21) oraz naukę o ciele chrześcijanina, które jest świątynią Boga (1 Kor 3,16; 6,19; 2 Kor 6,16).

Przeanalizowaliśmy te dwa terminy szczególnie $u$ św. Eukasza na tle także innych pism Nowego Testamentu, aby lepiej rozumieć, co może oznaczać ich brak zarówno w Mowie Szczepana jak i w Liście do Hebrajczyków, które obu tych terminów nie używają, choć podejmują tematykę miejsca świętego.

Oskarżyciele Szczepana stwierdzają, że nie przestaje on mówić przeciw temu świętemu miejscu, zapowiadając, że Jezus Nazarejczyk zburzy to miejsce. Chodzi o świątynię jerozolimską, ale nie została ona określona żadnym z dwu wyżej rozważanych terminów. Występuje ogólnie określenie miejsca świętego, a jego skonkretyzowanie dokonane jest przez użycie zaimka touton. W mowie, która jest odpowiedzią na zarzuty, Szczepan porusza sprawę przybytku, używając określenia skēnēe, gdy zaś wspomina budowę świątyni przez Salomona, mówi o domu Bożym oikos. Odrzucając zarzut występowania przeciw świątyni, Szczepan wykazuje jej względność. Dzieło ludzkie nie może być mieszkaniem Boga, którego stolicą jest niebo, a ziemia zaledwie podnóżkiem Jego stóp. Jakiż dom ludzie mogą zbudować Bogu? (7,48nn).

Myśl Szczepana nie jest szerzej rozwinięta, a niedoskonałość ziemskiego przybytku i doskonałość niebieskiego jest jednym z głównych tematów Listu do Hebrajczyków. Jezus ,,zasiadł po prawicy tronu Maje- 
statu w niebiosach jako sługa świątyni (tōn hagiōn) i prawdziwego przybytku (skene), zbudowanego przez Pana, a nie przez człowieka" $(8,1 \mathrm{n})$. Znajdujemy tu wspomniane już poprzednio powiązanie z Mową Szczepana poprzez myśl o zajęciu miejsca po prawicy tronu Majestatu. Podobna do Szczepanowej jest myśl o zbudowaniu przybytku przez Pana, a nie przez człowieka, jeżeli ma on być prawdziwy. Autor Listu do Hebrajczyków mówi o przybytku, używając tego samego terminu, który pojawia się w Mowie Szczepana (skēnēe). Termin ten w Liście do Hebrajczyków zachodzi aż dziesięć razy, podczas gdy w całym Nowym Testamencie znajdujemy go zaledwie dwadzieścia razy ${ }^{25}$. Autor Listu do Hebrajczyków stwierdza, że Mojżesz mając zbudować przybytek został pouczony przez Boga, aby uczynił wszystko według wzoru ukazanego mu na górze $(8,5)$. Tu powraca myśl o przybytku z czasów wędrówki przez pustynię. Mojżesz, który jest niższy od Chrystusa, buduje przybytek na wzór niebieski. Rzeczywistości ziemskie są jedynie odbiciem niebieskich. To niedoskonałe odbicie, jakim był przybytek ziemski, zostało w Liście do Hebrajczyków dokładniej opisane $(9,1-7)$. Dopóki jednak istnieje pierwszy przybytek, nie otwarta jest jeszcze droga do miejsca świętego. Chrystus natomiast jest arcykapłanem doskonalszego i nie ręką ludzką uczynionego przybytku $(9,11)$. Jeżeli więc ziemski przybytek potrzebował skropienia krwią ofiarniczą, rzeczy niebieskie doskonalszego potrzebują oczyszczenia $(9,21-23)$. Chrześcijanie zaś mają ołtarz, z którego nie mają prawa spożywać ci, którzy służą ziemskiemu przybytkowi $(13,10)$.

Taka jest nauka Listu do Hebrajczyków odnośnie do przybytku, którą staraliśmy się odczytać z tych miejsc Listu, w których Autor używa terminu skēnē. Termin ten spotykamy również w Mowie Szczepana. List do Hebrajczyków jest i tu kontynuacją myśli Szczepana. Szczepan oskarżony był o występowanie przeciw świątyni jerozolimskiej, która dla Żydów była największą świętością. W swej odpowiedzi Szczepan jakby abstrahuje od konkretnej budowli, powraca do rzeczywistości, którą można nazwać modelową, do przybytku zbudowanego przez Mojżesza na wzór podany mu z nieba. Ten przybytek, chociaż historyczna świątynia go zastąpiła, pozostał trwałym typem. Trudno stwierdzić, czy na świadomość Szczepana miało wpływ to, że ,zasłona świątyni” (tutaj występuje termin naos) rozdarła się przez środek (乇k 23,45). Redaktor Szczepanowej Mowy, św. Łukasz pisze o tym, korzystając ze wspólnej tradycji synoptycznej. Ta więc świątynia kończy swoją rolę, nie może jej zupełnie skończyć Mojżeszowy przybytek. Był typem, a więc trwa nadal w swym antytypie. Do niego nawiązuje również List do Hebrajczyków. Łukasz, pochodzący z pogaństwa, nigdy nie mógł być na właściwym terenie jerozolimskiej świąty-

25 Por. tamże, s. 141. 
ni. Raczej więc myśli kategoriami teologicznymi, zaczerpniętymi ze Starego Testamentu, w ramach których ważniejszy jest przybytek zbudowany przez Mojżesza od jerozolimskiej świątyni. Kontynuując myśl Szczepana, który w swych wywodach odszedł od konkretnej budowli świątynnej, Autor Listu do Hebrajczyków również nie ma jej na myśli, gdy mówi o miejscu świętym ${ }^{20}$. Ta uwaga jest istotna dla teologii Listu i rozstrzygnięcia problemu jego powstania.

\section{„Dopóki istnieje pierwszy przybytek” ( $\mathrm{Hbr} 9,8)$}

Autor Listu do Hebrajczyków charakteryzuje przybytek Starego Testamentu $(9,1-5)$ oraz istotne obrzędy liturgii starego przymierza $(9,6-7)$. Opis przybytku jest raczej skąpy, zwłaszcza odnośnie do miejsca najświętszego. Autor podkreśla jedynie bogaty jego wystrój. Z całej relacji wypływa wniosek pesymistyczny. Dostęp do przybytku był bowiem wielorako ograniczony, a skuteczność ofiar, które w nim składano, była niewielka. nie były $\mathrm{w}$ stanie udoskonalić człowieka ${ }^{27}$. W opisie przybytku i liturgii Autor Listu do Hebrajczyków posługuje się przekazem Starego Testamentu, zwłaszcza Księgi Wyjścia (rozdziały $25-27$; 36-38) ${ }^{28}$ oraz Kapłańskiej (szczególnie rozdział 16) ${ }^{29}$. Na tym tle wskazana jest rola Ducha Swiętego jako Tego, który nie tylko jest poręką nieomylności Pisma świętego, ale również odsłania symboliczny, typiczny sens rytu i jego znaczenie duchowe ${ }^{30}$. Objawiająca rola Ducha Swiętego dotyczy dwu etapów Bożej ekonomij zbawczej. Jeden ,jest obrazem czasu teraźniejszego, a składa się w nim ofiary, nie mogące udoskonalić w sumieniu tego, który spełnia służbę Bożą" $(9,9)$. Porządek ten trwa do czasu właściwego ustawienia rzeczy. Drugi etap jest zapoczątkowany zjawieniem się Chrystusa. Duch Swięty jest szczególnym interpretatorem dziejów zbawienia i ich biblijnej relacji. Tenże Duch Swięty sprawia także trwałość i duchową doskonałość Chrystusowego dzieła $(9,14)^{\text {s1. }}$. W tym kontekście czytamy

26 Por. L. Skwarczewski, Starotestamentowy kult ofiarniczy $w$ Liście do Hebrajczyków a w manuskryptach $i$ dokumentach $z$ Qumran (Sprawy biblijne XXIII) Poznań 1970, s. 94; J. Szlaga, Nowość przymierza Chrystusowego wediug Listu do Hebrajczyków, Lublin 1979, s. 58.

27 Por. J. Szlaga, Nowość przymierza..., s. 57-69.

28 Por. S. Ła c h, Księga Wyjscia. Wstęp-przektad z oryginatu - Komentarz, Poznań 1964, s. 240-253; 286-294.

29 Por. S. Ea ch, Księga Kapłańska. Wstęp - przekład z oryginału - Komentarz, Poznań 1970, s. 211-216.

${ }^{30}$ Por. C. S picq, L'Épitre aux Hébreux, 2, s. 253; A. J ankowski, List do Hebrajczyków, w: Komentarz praktyczny do Nowego Testamentu, praca zbiorowa, Poznań 1975, s. 1017; G. W. Buchanan, To the Hebrews (The Anochor Bible), New York 1972, s. 144.

81 Por. A. J a nkowski, Przez Ducha wiecznego" (Hbr 9,14). Próba uściślenia. sensu pneumatologicznego tego zwrotu. AnCrac 3 (1971), s. 201-220. 
przytoczone wyżej słowa o istnieniu przybytku. Wydawać by się mogło, że wzmianka ta pomaga w określeniu czasu powstania Listu do Hebrajczyków. Jeżeli istnieje jeszcze przybytek, rozumują ci, którzy dopatrują się w nim świątyni jerozolimskiej, to List musiał być napisany przed rokiem 70 po Chrystusie, w którym to roku świątynia definitywnie przestała istnieć. Argument oczywiście traci całą swą moc dowodową, jeżeli uwzględnimy to, co zostało już powiedziane, że Autor Listu do Hebrajczyków wyłączył świątynię jerozolimską z pola swego widzenia. Idee natomiast teologiczne nie przepadają w związku z tragicznymi wydarzeniami dotykającymi instytucji i budowli. Typiczna rola przybytku zbudowanego przez Mojżesza śmiało mogła przetrwać katastrofę roku siedemdziesiątego.

Pozostaje jeszcze jeden sposób argumentacji. Jeżeli wynik wojny żydowsko-rzymskiej doprowadził do ruiny świątyni i zaprzestania kultu, to najprostszym sposobem wykazania słabości instytucji Starego Testamentu było powołanie się na ten fakt. Jeżeli Autor Listu do Hebrajczyków tego nie czyni, można - zdaniem niektórych — wnosić, że pisał przed rokiem narodowej katastrofy. Tekst jednak samego Listu do takiego wniosku nie upoważnia. Zburzenie świątyni i zaprzestanie kultu nie zmieniają bowiem typicznej roli tego, co Duch Swięty objawia na kartach Pisma świętego. Istnienie przybytku jest obrazem czasu teraźniejszego, przeciwstawia mu Autor Listu do Hebrajczyków czas naprawy. Na oznaczenie czasu zastosowano w obu wypadkach grecki termin kairos; w odróżnieniu od terminu chronos określa on czas nie ilościowo, lecz jakościowo ${ }^{\mathbf{3 2}}$. Czas rozważany ilościowo to czas wyznaczany kolejnymi cyklami natury, czas kosmiczny, czas ciągłych powrotów ${ }^{38}$. Myśl biblijna podkreśla linearną koncepcję czasu, na jego osi rozważa momenty szczególnych interwencji Bożych. Należą one, zwłaszcza w perspektywie proroków Starego Testamentu, do czasu obecnego, przeżywanego aktualnie, wyznaczonego ekonomią synajskiego przymierza lub do czasu przyszłego, mesjańskiego, zapowiadanego i oczekiwanego. Te dwa czasy, czy lepiej dwa etapy, to dwie formy realizowania się spotkania Boga z ludźmi. Rozważając je jakościowo, nie musimy ściśle uwzględniać ich chronologicznego następstwa. Czas obecny poprzedza czas przyszły, gdyż ekonomia starego przymierza poprzedza ekonomię mesjańską, ale w okresie rodzącego się Kościoła trwa czas obecny (jeszcze) jak i rozpoczął się już czas przyszły. Autor Listu do Hebrajczyków opisując przybytek i kult i widząc w nich zapowiedź rzeczywistości pełniejszej (parabolē), stawia się w sytuacji Starego Testamentu, stąd jej przypisuje cechę obecności. Słusznie zaznacza M. Zerwick ${ }^{\mathbf{s}}$, że obecność ta może

32 Por. G. Dell ing, kairos, w: ThWNT 3, s. 456-463.

${ }^{88}$ Por. M. Join-Lambert, P. Grelot, Czas, w: STB, s. 175.

${ }^{34}$ Por. Analysis philologica Novi Testamenti Graeci, Romae 1966 , s. 511. 
oznaczać czas teraźniejszy piszącego, ale również odnosić się do czasu właściwego rozważanej rzeczywistości (pro suo tempore). W tym drugim znaczeniu Autor Listu do Hebrajczyków mówi o rzeczywistości, której przeciwstawia to, co u proroków rozważane było jako czas przyszły, tu zaś nazywa się czasem naprawy (diorthōseōs). Nie jest on ściśle przyszły, gdyż dla Autora jest już aktualny jako nowa rzeczywistość wprowadzona przez Chrystusa. Niesie on ze sobą uczestnictwo w dobrach przyszłych, a został zainicjowany interwencją Chrystusa, która jest interwencja dokonaną w określonym momencie czasu (aoryst: ,zjawiwszy się" oraz „wszedł”). Tę rzeczywistość gdzie indziej Autor Listu do Hebrajczyków określi przez „dziś” oznaczające szczególną fazę dziejów zbawienia (3,13; $4,7)^{35}$.

Chrześcijanin powołany jest do związania się z Chrystusem i wierności nowemu przymierzu. Przez to wchodzi on w czas naprawy. Niewierność, przed którą ostrzega List do Hebrajczyków, jest powrotem do rzeczywistości, którą określono jako czas teraźniejszy, jest to równocześnie zatrzymanie się na tej rzeczywistości, której symbolem jest przybytek Starego Testamentu. Kto tam się zatrzymuje, dla tego zamknięta jest droga do Miejsca świętego, którym jest świątynia niebieska jako rzeczywistość pełnego zjednoczenia z Chrystusem arcykapłanem. Autor Listu widzi realne niebezpieczeństwo takiego zatrzymania się i przed nim przestrzega. Nieprzyjęcie czy porzucenie nowego przymierza będzie zawsze zatrzymaniem się na poprzednim, niedoskonałym etapie bez względu na to, czy instytucje z nim związane realnie istnieją, czy zostały zburzone przez siły fizyczne. Ich byt, o który chodzi w Liście do Hebrajczyków, jest niezależny od porządku fizycznego. Zburzenie więc świątyni i katastrofa roku siedemdziesiątego odnoszą się do innej płaszczyzny, z której argumentacja w wywodach Autora nie jest zupełnie konieczna. Nie byłaby także przekonywająca. Swiątynia leżała już poprzednio w gruzach, a naród został uprowadzony do Babilonii. Była to realizacja gróźb proroków (por. 2 Krn 36,15n), ale w niczym nie stanowiła dowodu końca rzeczywistości przymierza synajskiego. Zbudowana ręką ludzką świątynia może stać lub leżec w gruzach, a rzeczywistość religijna rozwija się swoim torem.

Chrystus - Kapłan

Rozważana poprzednio kwestia istnienia przybytku nie rozstrzyga sprawy powstania Listu do Hebrajczyków. Nie ma podstaw do wnioskowa-

${ }^{35}$ Por. J. Moffatt, A Critical and Exegetical Commentary on the Epistle to the Hebrews, Edinburgh ${ }^{3} 1948$, s. 9. 
nia, że List musiał powstać przed rokiem 70. Na późniejszy natomiast czas powstania Listu wskazuje między innymi zastosowanie do Chrystusa tytułu kapłana. Wynika ono z wewnętrznych racji samego Listu. List do Hebrajczyków jest kontynuacją Mowy Szczepana. Ponieważ Szczepan odpowiada na zarzuty, z których pierwszy odnosił się do przeciwstawiania się świątyni, dlatego List do Hebrajczyków ukazuje Jezusa jako kapłana nowego porządku. Wchodzi On do nowego przybytku i nie niszcząc tego, co było, tak przewyższa tamtą rzeczywistość, że przybytek starego przymierza okazuje się jedynie cieniem rzeczywistości przyszłej.

W Liście do Hebrajczyków pojawia się więc nowe na terenie Nowego Testamentu sformułowanie myśli o kapłaństwie Chrystusa. Chodzi - sformułowanie, gdyż przesłanki nauki o kapłaństwie Chrystusa znajdują się także w innych warstwach Nowego Testamentu, ale nigdzie nie jest On expressis verbis nazwany kapłanem ${ }^{36}$. List do Hebrajczyków stosuje do Chrystusa określenie kapłan (hiereus) i arcykapłan (archiereus). Zastosowanie tych terminów stało się możliwe dopiero po roku 70, gdy kapłaństwo Starego Testamentu odeszło w mroki historii. Wcześniej można było czynić aluzje do kapłańskich czynności i prerogatyw, jak spotykamy to w licznych pismach Nowego Testamentu, ale sam termin zarezerwowany był dla istniejącej i ściśle zamkniętej w sobie instytucji. Kapłan musiał pochodzić z pokolenia Lewiego, a Jezus pochodził z pokolenia Judy. Kiedy lewickie kapłaństwo zeszło z areny dziejów, Autor Listu do Hebrajczyków mógł termin zastosować do Chrystusa, sięga on jednak do głębokich korzeni kapłaństwa, ukazując to, co było bardziej ogólne i podstawowe w kapłaństwie niż kapłaństwo lewickie. Chrystus jest kapłanem na wzór Melchizedeka. Autor Listu do Hebrajczyków sięga więc tutaj do postaci, która wyprzedza ustanowienie kapłaństwa przez Mojżesza w związku z przymierzem synajskim ${ }^{37}$.

Równocześnie warto zaznaczyć, że sformułowania o Chrystusie arcykapłanie nie mogły się pojawić dokąd istniała instytucja arcykapłana izraelskiego. W czasach bowiem powstawania Nowego Testamentu była ona do ona zdyskredytowana. W religii izraelskiej arcykapłan odgrywał zawsze rolę naczelną. Funkcję tę sprawowali potomkowie Aarona, była ona dziedziczna i dożywotnia. Do czasów niewoli inwestytura odbywała się przez włożenie szat i namaszczenie, po niewoli pozostało tylko przekazywanie szat arcykapłańskich. W czasach perskich i pod panowaniem Ptolemeuszów arcykapłani de facto byli przedstawicielami narodu i jego kierownikami. Sytuacja zmieniła się za Seleucydów. Seleukos IV odsunął bowiem od god-

${ }^{36}$ Por. A. J a nkowski, K. Romaniuk, Kapłaństwo w Piśmie świętym Nowego Testamentu (Attende lectioni I) Katowice 1972, s. 38-51.

${ }_{37}$ Por. T. Jelonek, Chrystologia Listu do Hebrajczyków, AnCrac 17 (1985), s. $253-257$. 
ności arcykapłańskiej legalnego arcykapłana Oniasza III, męża wielkiej szlachetności, a urząd arcykapłana sprzedał jego bratu, Jazonowi. Oniasz oskarżony o naruszanie ładu w państwie został zamordowany. Przez Seleucydów mianowani byli arcykapłanami oprócz Jazona także Menelaos i Alkimos. Wszyscy oni byli narzędziami hellenizacji, a więc przyczyniali się do zagłady religii, w której spełniali najwyższy urząd. Menelaos na domiar złego nie pochodził nawet z pokolenia Lewiego, był więc podwójnie bezprawnie mianowany. $\mathrm{Z}$ rąk obcych władców otrzymał także godność arcykapłana Jonatan, sprytny przywódca walk wyzwoleńczych. Jego brat i następca, Szymon również otrzymał tę godność od obcych, choć po uzyskaniu niepodległości starał się uprawomocnić tę nominację przez odwołanie się do zgromadzenia ludu. Jonatan i Szymon pochodzili z pokolenia Lewiego, ale nie należeli do potomków Aarona. Ich arcykapłaństwo było więc uzurpacją, a otrzymane od pogańskich władców budziło sprzeciw. Dlatego autor Drugiej Księgi Machabejskiej ogranicza swoją relację jedynie do czasów Judy Machabeusza, pomijając nawet w tym okresie czyny jego braci. Był to swoisty protest przeciw temu, co działo się z godnością arcykapłana ${ }^{38}$. Następnie godność arcykapłańską piastowali przedstawiciele rodziny machabejskiej i dynastii hasmonejskiej. Sciągnęli oni na siebie zarzut, że zajmują się bardziej prowadzeniem wojen i polityką dynastyczną niż sprawami religii. Zgorszeniem było zwłaszcza postępowanie Aleksandra Janneusza, który prowadząc liczne wojny skrwawionymi rękami składał ofiarę. Do funkcji bowiem arcykapłana należało złożenie ofiary w Dniu Pojednania i wtedy wchodził on do miejsca najświętszego. Od czasów Heroda arcykapłani byli mianowani i zrzucani przez sprawujących władzę polityczną. Otrzymywał tę godność ten, kto więcej zapłacił. Usunięty od władzy arcykapłan nazywał się nadal arcykapłanem, dlatego w Ewangeliach mowa jest o nich w liczbie mnogiej. Wielkie znaczenie miał arcykapłan Annasz, który, choć sam odsunięty od godności, kierował polityką swoich pięciu synów i zięcia Kajfasza, przez długie lata piastujących urząd arcykapłański. Najdłużej sprawował tę funkcję Józef Kajfasz od 18 do 36 roku po Chrystusie. Tradycja żydowska o całej rodzinie wyraża się z pogardą, a Talmud mówi o wężowym syku Annasza. Arcykapłaństwo stało się więc przedmiotem przetargów politycznych, a przez przekupstwo straciło swój religijny autorytet. W tym świetle nie dziwi nas fakt, że powstańcy w Jerozolimie na szyderstwo mianowali arcykapłana Fanniego, syna Samuela, który pochodził z rodu kapłańskiego, ale był kamieniarzem na głuchej prowincji i człowiekiem bardzo prymitywnym ${ }^{3 *}$ Akt ten był wyszydzeniem stanowiska, które straciło swój prestiż i zna-

${ }^{88}$ Por. F. Grylewicz, Księgi Machabejskie, Poznań 1961, s. 258.

${ }^{39}$ Por. J. Fla wi u s z, Wojna żydowska, (przelożył oraz wstępem i komentarzem opatrzył J. Radożycki), Poznań 1980, IV, 3,8. 
czenie. I tak odeszło w przeszłość arcykapłaństwo Starego Testamentu ${ }^{40}$.

Czy w takiej sytuacji można było zastosować tak zdyskredytowany tytuł do Chrystusa? Czy można było napisać: „Każdy bowiem arcykapłan z ludzi brany, dla ludzi bywa ustanawiany w sprawach odnoszących się do Boga... I nikt sam sobie nie bierze tej godności, lecz tylko ten, kto jest powołany przez Boga jak Aaron" $(5,1.4)$ ? Takich słów nie można było napisać w czasie, gdy nazwa arcykapłana oznaczała Annasza, Kajfasza czy Fanniego. Do idealnej i typicznej treści tego terminu, wynikających z przekazu Starego Testamentu, można było powrócić, gdy historyczne realia przestały ciążyć w ludzkiej świadomości.

\section{Kapłaństwo Jezusa - idea Łukaszowa}

Podkreślaliśmy już poprzednio, że ukazanie kapłańskiej godności Jezusa jest w Liście do Hebrajczyków wyznaczone jego właściwym tematem. Jako dokończenie Mowy Szczepana List do Hebrajczyków ukazuje Jezusa, który przez nowe i doskonalsze przymierze oraz przez nowe i wyższe kapłaństwo nie sprzeciwia się wartościom Starego Testamentu - świątyni i prawu Mojżesza, ale je przerasta. Problematyka więc kapłaństwa w Liście do Hebrajczyków związana jest ściśle z jego celem i konstrukcją. Jest ona również pomostem między tym Listem a Ewangelią Łukaszową. Nie przypadkowo tradycja przydzieliła temu Ewangeliście symbol wołu jako zwierzęcia ofiarnego. Problematyka świątyni, ofiary i kapłaństwa przenika bowiem przede wszystkim Eukaszową Ewangelię Dzieciństwa (Łk 1-2). Dwa pierwsze rozdziały Trzeciej Ewangelii ze względu na swoją strukturę i teologię przedstawiają wielkie bogactwo tematów teologicznych. Nie wdając się w dyskusję dotyczącą gatunku literackiego rozważanego tekstu ${ }^{41}$, trzeba zaznaczyć, że jest ona teologicznym przedstawieniem postaci Jezusa, którego publiczna działalność opisana została w dalszych rozdziałach Eukaszowej Ewangelii.

Pierwsza scena Łukaszowej Ewangelii Dziecięctwa rozgrywa się w świątyni, tam Zachariasz, sprawujący funkcje kultyczne, otrzymuje zapowiedź narodzin Jana Chrzciciela. W świątyni zjawia się Mesjasz jako

Por. E. Dąbrowski, Nowy Testament na tle epoki. Geografia. Historia. Kultura, Poznań ${ }^{2}$ 1965, s. 370-381; W. Gnutek, Srodowisko Nowego Testamentu, w: Wstep do Nowego Testamentu, praca zbiorowa, Poznań 1969, s. 34n.

${ }_{41}$ Por. J. Wilk, Teologia Eukaszowej Ewangelii Dzieciństwa, w: Studia z teologii św. Łukasza, praca zbiorowa, Poznań 1973, s. 105-124; W. S o to w sk i, Ewangelia Dziecięctwa według św. Łukasza, w: Chrystus i Kościót, praca zbiorowa, Lublin 1979 3. $13 \mathrm{n} ;$ K. H. Schelkle, Dzieciństwo Jezusa, w: Biblia dzisiaj, praca zbiorowa, Kraków 1969, s. 241-245; R. Laurentin, Structure et théologie de Luc I-II (Etudes Bibliques), Paris 1957, s. 93nn. 
czterdziestodniowe dziecię przyniesione, aby było stawione przed Panem zgodnie z prawem Mojżeszowym. To wejście do świątyni w Łukaszowej Ewangelii Dziecięctwa szczególnie jest podkreślone. Ostatnia scena tego zwartego w sobie tekstu również odbywa się w świątyni, do której przy bywa dwunastoletni Jezus i zostaje tam odnaleziony przez rodziców, którym oznajmia, że powinien przebywać w domu Ojca. Ewangelię Dzieciństwa rozpoczyna ofiara kadzielna, która jest aktem kultu. Czynność kultyczna wspomniana jest przy okazji obrzezania i święta Paschy. Egzegeci dopatrują się powiązań liturgicznych w kantykach Łukaszowej Ewangelii Dziecięctwa, a sceny zwiastowania i chóry anielskie przy narodzeniu Jezusa reprezentują coś z liturgii niebieskiej ${ }^{42}$. Swiątynia i kult liturgiczny są więc nieodłącznym tłem całego opowiadania. Wymagają one kapłaństwa, a przecież kapłan Zachariasz, starzec Symeon czy inni liturdzy nie stanowią centralnych postaci tego opowiadania. Czy można wyczuć tu jakby pustkę, którą ma napełnić Ten, którego przyjście jako Mesjasza wypełnia teologiczną wizję Ewangelii Dziecięctwa? Św. Łukasz nie nazwie Jezusa kapłanem, ale dyskretnie podkreśli Jego arcykapłańskie pochodzenie obok bardzo eksponowanego pochodzenia z rodu Dawida. Elżbieta jest krewną Maryi (Łk 1,36), a o Elżbiecie wyraźnie zostało powiedziane, że była z rodu Aarona $(1,5)$. W związku z powszechnym oczekiwaniem Proroka, Króla i Kapłana lub, jak ujęte to zostało w Qumran, Mesjasza Izraela i Mesjasza Aarona, Ewangelia Dziecięctwa wyraźnie pokazuje, że funkcje Proroka spełni Jan jako Poprzednik, natomiast Jezus, Syn Boży, podejmie dwie następne funkcje ${ }^{43}$. Pozostajemy więc stale na terenie aluzji, ale są one dość wyraźne, aby w Łukaszowej Ewangelii Dziecięctwa dostrzec myśl o kapłaństwie Jezusa, nawet arcykapłaństwie, jeżeli powiązania prowadzą do osoby Aarona. Jezus jednak według pochodzenia swego domniemanego ojca będzie pochodził z pokolenia Judy, a Jego kapłaństwo nigdy nie będzie kapłaństwem lewickim. Stąd też konieczność takiego właśnie zawoalowanego sposobu przedstawienia myśli o Jezusie jako kapłanie.

Myśl ta powraca na końcu Trzeciej Ewangelii, znów także w formie delikatnej aluzji. Scena wniebowstąpienia Chrystusa (24,50n) jest dla konstrukcji całej Trzeciej Ewangelii bardzo istotna. Ku niej zdąża cała relacja. I oto objawienie się Chrystusa w opisie wniebowstąpienia ma charakter uroczysty i liturgiczny. Czyni to tak jak czynili arcykapłani zwłaszcza w Dniu Pojednania (por. Syr 50,20n) ${ }^{44}$. Wspomniana w na-

42 Por. J. Wilk, Teologia Łukaszowej Ewangelii Dzieciństwa, s. 118.

${ }_{43}$ Por. R. P ind e 1, Paralele między Janem Chrzcicielem a Jezusem $w$ opisach zwiastowań $w$ Ewangelii św. Łukasza, praca magisterska (w maszynopisie), Kraków 1982 , s. 66 n.

${ }_{44}$ Por. J. Each, Opisy wniebowstapienia Jezusa, w: W kierunku Prawdy, dzieło zbiorowe, Warszawa 1976, s. 69 n. 
stępnym wierszu radość uczniów przypomina radość, o jakiej mówi Księga Kapłańska w związku z pierwszym błogosławieństwem Aarona (9;24). Mamy zatem znów aluzję do Chrystusowego kapłaństwa. Dlatego mogliśmy w tytule niniejszego punktu rozważań zaznaczyć, że kapłaństwo Jezusa jest ideą Łukaszową.

Wykryliśmy więc nowe powiązanie Trzeciej Ewangelii jako pisma Łukaszowego z Listem do Hebrajczyków. Warto jeszcze podkreślić, ze na końcu Ewangelii aluzja kapłańska wiąże się z wniebowstąpieniem i Dniem Pojednania. Kapłański charakter wniebowstąpienia jest centralną ideą Listu do Hebrajczyków, a liturgia Dnia Pojednania stanowi w nim typ Chrystusowego wejścia z własną krwią do sanktuarium niebieskiego. Jesteśmy więc we wspólnym kręgu myśli i idei. Podkreślenie tej wspólnoty umacnia hipotezę Łukaszowego autorstwa Listu do Hebrajczyków.

Niektóre powiazania z pismami Łukasza

Przeprowadzone już poprzednio rozważania nie zmierzały do ściślejszego określenia czasu powstania Listu do Hebrajczyków, choć dawały pewne wskazówki mogące służyć rozwiązaniu tego problemu. List ze względu na swoją treść teologiczną i sposób jej wyrażenia jest późniejszym pismem Nowego Testamentu, ale określenie jakichś dat wydaje się zbyt pochopne. Natomiast mieliśmy okazję przy poprzednich rozważaniach ukazać pewne powiązania Listu do Hebrajczyków z innymi pismami Łukasza, konkretnie z jego Ewangelią. Ten problem będziemy obecnie kontynuować, zastrzegając się na początku, że poruszone zostaną tu tylko nieliczne zagadnienia $\mathrm{z}$ bardzo obszernego repertuaru możliwych do ujawnienia powiązań. Szczególną uwagę obecnie zwrócimy na te zagadnienia, które już poprzednio zostały podjęte i rozwiązane przez autora niniejszej rozprawy. Ze względu na istniejące publikacje, dotyczące tych zagadnien, ograniczymy się jedynie do ich streszczenia.

W poszukiwaniu powiązań Listu do Hebrajczyków z innymi pismami św. Eukasza trzeba najpierw uwzględnić niewielki fragment Listu, jakim są niecałe dwa wiersze rozdziału drugiego (2,3b.4). Fragment ten zawiera sformułowanie, które stanowi jeden $\mathrm{z}$ argumentów przeciw Pawłowemu autorstwu Listu. Paweł bowiem nie mógł utożsamiać się z adresatami i zaliczać do drugiej generacji chrześcijan ${ }^{45}$. W poprzedzającym kontekście Autor przeciwstawia mocnej mowie przekazanej przez aniołów to, co jest mocniejsze - zbawienie właściwe nowemu przymierzu ${ }^{46}$. To prowadzi do

45 Por. J. Frankowski, Problem autorstwa... (zmiana stanowiska), s. 15.

${ }_{46}$ Por. A. V a nhoye, Situation du Christ. Épitre aux Hébreux 1 et 2 (Lectio Divina 58), Paris 1969 , s. 238. 
streszczenia dziejów głoszenia, umacniania i poświadczania zbawienia. Dokładna analiza tego fragmentu ${ }^{47}$ pozwala wyciągnąc wniosek, że jest on świadomym streszczeniem relacji Trzeciej Ewangelii i Dziejów Apostolskich. Autor Listu do Hebrajczyków nie tylko nawiązuje do dwu dzieł Łukaszowych, ale potrafi w tak krótkich sformułowaniach dotknąć najważniejszych ich punktów. Autor Listu do Hebrajczyków jest mistrzem syntezy, ale kto może najlepiej znać istotne nurty Trzeciej Ewangelii i Dziejów Apostolskich, jeżeli nie sam ich autor. Dlatego w śledzonym streszczeniu można zobaczyć nie tylko zależność literacką, lecz także tożsamość autora wszystkich trzech pism Nowego Testamentu.

W rozważanym wyżej fragmencie Listu do Hebrajczyków spotykamy wzmiankę o Duchu Swiętym. Panuje powszechne przekonanie, że List do Hebrajczyków niewiele miejsca poświęca Duchowi Swiętemu. Wysuwa się to czasem nawet jako argument przeciw Eukaszowemu autorstwu Listu, gdyż - jak wiemy - Trzecia Ewangelia, a szczególnie Dzieje Apostolskie zwane Ewangelią Ducha Swiętego zawierają bogatą treść pneumatologiczną. W związku z tym przeprowadzono szczegółową analizę miejsc Listu do Hebrajczyków wspominających Ducha Swiętego i rozpatrzono rolę, jaką nauka o Duchu Swiętym odgrywa w teologii Listu ${ }^{48}$. Analiza ta prowadzi do wniosku, że Duch Swięty, o którym Autor nie mówi zbyt wiele, odgrywa zasadniczą rolę $w$ teologii Listu. To On jest sprawcą wyższości i doskonałości nowego przymierza. Przeciwstawienie doskonałości nowego przymierza niedoskonałości starego jest główną myślą Listu, z której płyną wnioski praktyczne, a przede wszystkim wezwanie do wierności. Wzmianki o Duchu Swiętym wiążą się ze wspomnianym przeciwstawieniem i występują w kontekście natarczywego wezwania do wierności. Nowy porządek jest porządkiem sprawionym przez Ducha Swiętego. On go również gwarantuje i objawia. Prześledzenie zatem odnośnych miejsc Listu do Hebrajczyków pozwala zobaczyć istotną rolę Ducha Swiętego, o którym w niewielu miejscach, ale wiele zostało powiedziane. Autor Listu do Hebrajczyków docenia rolę Ducha Świętego, a siedmiokrotne Jego wzmiankowanie nabiera rzeczywiście symbolicznego znaczenia związanego z liczbą siedem. Rzeczywistość nowego przymierza, którą List do Hebrajczyków stara się gruntownie omówić, staje się pełna i doskonała dzięki Duchowi Swiętemu. Jej obraz, dzięki siedmiokrotnemu przywołaniu Ducha Świętego, określonego także Duchem wiecznym i Duchem łaski, staje się wypełniony pneumatyczną treścią. Pod względem więc tak ważnego aspektu, jakim jest nauka o Duchu Świętym, nie można podkreślać różnicy między Listem do Hebrajczyków a innymi pismami Łukasza. Omó-

47 Por. T. Jel onek, Streszczenie dzieł Eukaszowych..., Tenże, Poświadczajace dzieta Boga...

18 Por. T. J elonek, Rola Ducha Swiętego... 
wione zaś poprzednio zagadnienie streszczenia Dziejów Apostolskich w Liście do Hebrajczyków pokazuje, że nauka o Duchu Swiętym nie tylko nie dzieli tych pism, ale stanowi jedno z łączących je przęseł.

Wykazano ${ }^{49}$, że Łukasz w Trzeciej Ewangelii nadaje terminowi „dziś” (sēmeron) specyficzny, soteryjny charakter, nie pozbawiając $\mathrm{w}$ żadnym z przytoczonych miejsc tego terminu jego podstawowego znaczenia dnia bieżącego trwającego od zachodu do zachodu. Teologiczne i soteryjne znaczenie ma natomiast „dziś" występujące w Dziejach Apostolskich w cytacie Psalmu 2, przytoczonego przez Pawła w Antiochii Pizydyjskiej $(13,33)$. Na słowa Psalmu powołuje się Paweł głosząc dobrą nowinę o zmartwychwstaniu Chrystusa. Tylko, że to „dziś”, w odróżnieniu od Ewangelii Łukaszowej, zatraca prawdopodobnie w dużym stopniu swoje podstawowe znaczenie. Jest to dziś bardziej wieczne niż dziś od zachodu do zachodu słońca. Na tle tych spostrzeżeń odnośnie do Łukaszowego stosowania terminu zauważmy, że List do Hebrajczyków stosunkowo często używa ten termin szczególnie Łukaszowy. Dwa razy cytowany jest Psalm 2, o którym to cytacie mówiliśmy powyżej odnośnie do Dziejów Apostolskich. Do tego znaczenia zbliża się znaczenie terminu użytego w rozdziale trzynastym $(13,8)$. Trzy razy „dziś” występuje w cytowanym urywku Psalmu $95(3,7.15 ; 4,7)$ i dwa razy w homiletycznej parenezie opartej na słowach tego Psalmu $(3,13 ; 4,7)$. To ,dziś" jest dniem wyznaczonym przez Boga, oznacza specjalną fazę zbawienia. Czy jednak nie można temu „dziś” nadać także Łukaszowego znaczenia? Przecież każda pareneza ma uaktualnić prawdę objawioną, przedstawić ją jako zadanie na chwilę obecną. To dziś aktualnie przez nas przeżywane jest przecież czasem, który trzeba wykorzystać. Takie potraktowanie każdego „dziś” jako „dziś” Łukaszowego, jakim było „dziś” pasterzy, Zacheusza czy dobrego łotra, wydaje się bardzo odpowiadać swoistej eschatologii Listu do Hebrajczyków.

$\mathrm{Na}$ zakończenie tego punktu rozważań zauważmy jeszcze, że zrozumienie chrystologii Listu do Hebrajczyków wymaga uprzedniego oświetlenia podstaw, $\mathrm{z}$ których ona wypływa ${ }^{50}$. Wykazaliśmy ${ }^{51}$, że przyjęcie Listu do Hebrajczyków jako kontynuacji Mowy Szczepana tłumaczy kształt jego chrystologii i wiąże tym samym List do Hebrajczyków z pismami Łukasza.

49 Por. T. Jelonek, Zbawcze znaczenie Eukaszowego „dzisiaj”, RuBib 27 (1975), s. $107-113$

${ }_{50}$ Por. H. L a ngk a m mer, List do Hebrajczyków i jego chrystologiczna orientacja, w: Materiały pomocnicze do wykładów biblistyki IV, Lublin 1979, s. 114.

51 Por. T. Jelon ek, Chrystologia Listu do Hebrajczyków. 


\section{Jeszcze o innych powiąaniach}

Poprzedni punkt rozważań poświęcony został tym powiązaniom Listu do Hebrajczyków z pozostałymi pismami św. Łukasza, które zostały wcześniej już rozpracowane przez autora niniejszej rozprawy. Tu zatem podano jedynie streszczenie odpowiednich publikacji, a szczególnie ich wnioski końcowe. Obecnie uzupełnimy poprzednie rozważania kilkoma uwagami kontynuującymi podjęty temat. Umieszczony w tym punkcie przegląd zagadnień ma charakter wzmiankowy. Każdy problem wymagałby osobnego potraktowania i szerszego rozpracowania. Jak już wspomniano, ilość możliwych tematów jest ogromna. Nie jest zadaniem niniejszej pracy ich rozpatrzenie. Także nie miejsce tu, aby wiele $\mathrm{z}$ nich gruntowniej omówić Ponieważ jednak mogą do całości obrazu dorzucić nowe argumenty, wydaje się słuszne przytoczenie choćby niektórych $\mathrm{z}$ nich zaledwie $\mathrm{w}$ charakterze wzmianki. Nie będziemy zatem przeprowadzać tu badań i wyciągać solidnie udokumentowanych wniosków. Podamy raczej jedynie problemy, które wymagają dokładniejszej analizy, a zostaną wspomniane, gdyż na pierwszy rzut oka wydają się pomocne w ustaleniu szukanych powiązań Listu do Hebrajczyków i pozostałych pism Eukasza. Jest to zatem raczej zestaw problemów do opracowania niż przegląd wniosków i tak trzeba traktować siłę dowodową tego, co zostanie tu przytoczone.

List do Hebrajczyków rozpoczyna się od prologu, którym poprzednio zajmowaliśmy się ze względu na powiązania między epilogiem Mowy Szczepana a początkiem jej kontynuacji w Liście. Na prolog Listu warto również popatrzeć z innego punktu widzenia. Nie jest on epistolarnym początkiem księgi, jak występuje to w Listach Pawłowych i innych epistolarnych pismach Nowego Testamentu z wyjątkiem Pierwszego Listu św. Jana. Prolog Listu do Hebrajczyków podobnie jak prolog Janowej Ewangelii ${ }^{52}$ jest fragmentem niezwykle bogatym w treść teologiczną ${ }^{53}$. Ukazuje ona ramy dziejów zbawienia, w których centralną postacią jest Jezus Chrystus. I w tym punkcie prolog Listu do Hebrajczyków upodabnia się do prologów, jakimi św. Łukasz rozpoczyna Trzecią Ewangelię i Dzieje Apostolskie. Tamte prologi są zarazem dedykacjami, które zwracają się do dostojnego Teofila. W obu jednak zwrócono uwagę na przełomowe znaczenie postaci Jezusa. Jego działalność jest jakimś początkiem. W obu prologach Łukaszowych zwrócona jest uwaga na przekaz objawienia, o którym także czytamy w prologu Listu do Hebrajczyków.

52 Por. L. Sta chowiak, Ewangelia św. Jana. Wstęp - przekład z oryginaŁu - komentarz, Poznań 1975, s. 99-103.

53 Por. A. Vanhoye, Christologia a qua initium sumit epistola ad Hebraeos (Hebr 1,2b.3.4), VD 43 (1965), s. 3-14; 49-61; 113-123; J. Frankowski, Petne ramy dziejów zbawienia: przez Syna i dla Syna (Hebr 1,2b), w: Warszawskie Studia Biblijne, praca zbiorowa, Warszawa 1976, s. 138-147. 
Następnym punktem stycznym może być zestawienie zdania z Listu do Hebrajczyków: „Skoro zaś znowu wprowadzi Pierworodnego na świat, powie: Niech Mu oddają pokłon wszyscy aniołowie Boży" (1,6) z Łukaszowym opisem narodzenia Jezusa. W nim Jezus nazwany jest również pierworodnym (Łk 2,7 ${ }^{\mathbf{5 4}}$, a nad żłóbkiem pojawiają się zastępy niebieskie wielbiące Boga $(2,13)$.

Stwierdzenie Listu do Hebrajczyków: ,Z głośnym wołaniem i płaczem za dni ciała swego zanosił On gorące prośby i błagania do Tego, który mógł Go wybawić od śmierci, i został wysłuchany dzięki swej uległości" (5,7) może być rozpatrywane na tle szczególnego zainteresowania Ewangelii Łukaszowej sceną modlitwy Jezusa w Ogrojcu ${ }^{55}$, w której tenże Ewangelista przytacza fakt pocieszenia Jezusa przez anioła (Łk 22,43), będącego szczególnym znakiem wysłuchania Jezusowej modlitwy przez Ojca $^{56}$.

W Ewangelii św. Łukasza czytamy, że największą radością ucznia ma być to, że jego imię zapisane jest w niebie $(10,20)$. Myśl o zapisaniu w niebie powraca w Liście do Hebrajczyków. Pierworodni, których zgromadzenie oznacza Kościół na ziemi, zapisani są w niebiosach $(12,23)^{57}$.

W Ewangelii Łukaszowej rozwinięta jest eschatologia indywidualna. Podkreśla ona rozstrzygające znaczenie momentu śmierci ${ }^{58}$. Odpowiada tej myśli zdanie Listu do Hebrajczyków: „postanowiono ludziom raz umrzeć, a potem sąd" $(9,27)$.

W następnym wierszu Listu do Hebrajczyków podkreślone zostało, że powtórne przyjście Chrystusa, mające charakter zbawczy, będzie przyjściem do tych, którzy Go oczekują $(9,28)$. Idea oczekiwania wyraźnie jest podkreślona w rozdziale jedenastym, ukazującym przykłady wiary. Sama wiara jest poręką dóbr, których się spodziewamy $(11,1)$. Oczekiwaniem jest życie chrześcijanina, w którym szuka on miasta, mającego przyjść $(13,14)$. Idea oczekiwania jest równocześnie teologumenem Łukasza. Wystarczy zwrócić uwagę na pouczenie o gotowości na przyjście Pana (12,35-40)

54 Por. T. Jel on ek, „Zgromadzenie pierworodnych zapisanych $w$ niebiosach" Hbr 12,23a. Przyczynek do eklezjologii Nowego Testamentu, AnCrac 10 (1978), s. $173-175$.

55 Por. F. Gryglewicz, Ewangelia wedtug św. Eukasza, Poznań 1974, s. 333-335; R. Bartnicki, Ewangeliczne opisy męki w aspekcie literackim, teologicznym $i$ kerygmatycznym, w: Studia $z$ Biblistyki III, praca zbiorowa, Warszawa 1983 , s. 151.

${ }_{56}$ Por. A. Feuillet, L'évocation de ,l'agone" de Gethsemani dans l'épitre aux Hébreux (5,7-8), „Esprit et Vie" 86 (1976), s. 49-53.

57 Por. T. Jelo nek, „Zgromadzenie pierworodnych...”, s. 175-177; L. Léc uyer, Ecclesia primitivorum, w: Analecta Biblica 17-18, Romae 1963, 2, s. $161-168$.

58 Por. A. Jankowski, Doniosłość Łukaszowej eschatologii indywidualnej, RuBib 28 (1975), s. 168-182; A. S ob ota, Sytuacja egzystencjalna cztowieka w kontekście śmierci według św. Łukasza, praca magisterska (w maszynopisie), Kraków 1984, passim. 
i na Łukaszowy akcent w mowie eschatologicznej: „A gdy się to dziać zacznie, nabierzcie ducha i podnieście głowy, ponieważ zbliża się wasze odkupienie" $(21,28)$. To stwierdzenie wyraźnie koresponduje ze wspomnianym określeniem paruzji w Liście do Hebrajczyków $(9,28)$.

G. Voss ${ }^{59}$ rozważając rozumienie wiary $\mathrm{w}$ pismach Łukaszowych podkreśla, że w myśli Łukasza realizacja wiary dokonuje się jako naśladowanie Jezusa, który, podobnie jak stwierdza to List do Hebrajczyków, ustanowił drogę wiodącą do żywota i sam jest przewodnikiem. Dlatego całe życie ziemskie Jezusa ważne jest dla kerygmatu. Widzimy to w Dziejach Apostolskich $(1,21 \mathrm{n} ; 5,20)$. Stwierdzamy równocześnie, że w całej epistolarnej części Nowego Testamentu List do Hebrajczyków jest pismem, które najwięcej nawiązuje do życia Jezusa ${ }^{60}$. On zaś sam nazwany jest także przewodnikiem $(2,10 ; 12,2)$.

Zaznaczone podobieństwa wymagają, jak stwierdziliśmy wyżej, głębszego rozpracowania, obrazują jednak zarówno zakres możliwych problemów, jak i rozmaitość więzów, jakie możemy wyłuskać odnośnie do Listu do Hebrajczyków i pozostałych pism Łukaszowych. Na tych kilku przykładach tu pozostaniemy.

\section{Adresaci Listu}

Z problemem autorstwa Listu do Hebrajczyków wiąże się również problem jego adresatów. Jest to problem bardzo dyskutowany i daleko $\mathrm{mu}$ do jednoznacznego rozwiązania. W tym miejscu wypada, aby w jakiś sposób ustosunkować się do tego zagadnienia. H. Langkammer ${ }^{61}$ liczne hipotezy sprowadza do trzech zasadniczych:

— jakiś kościół lokalny (Rzym, Jerozolima, Efez lub inny);

- pewne ugrupowanie w kościele lokalnym;

- grupy bez lokalizacji (Qumrańczycy, byli kapłani lewiccy).

Hipotezę skierowania Listu w obecnej formie do chrześcijan prześladowanych w ogarniętej wojną z Rzymianami Jerozolimie ${ }^{62}$ odrzucamy ze względu na rozważany poprzednio czas powstania Listu. Natomiast z tego okresu mogło pochodzić hipotetyczne, krótkie pismo samego Pawła, o którym wspominaliśmy wyżej, a które zostało napisane w języku hebrajskim. Szczegółowa analiza zagadnień kultycznych w Liście do Hebrajczyków i w dokumentach qumrańskich doprowadziła do negatywnej

59 Wiara $w$ rozumieniu Nowego Testamentu, w: Biblia dzisiaj, praca zbiorowa, Kraków 1969, s. 383.

${ }_{60}$ Por. G. Hughes, Hebrews and hermeneutics (Society for New Testament Studies Monograph Series 36) Cambridge 1979, s. 75.

${ }^{61}$ Por. List do Hebrajczyków i jego chrystologiczna orientacja, jw. s. 115.

${ }_{62}$ Por. A. J ankowski, List do Hebrajczyków, w: Komentarz praktyczny do Nowego Testamentu, s. 991. 
odpowiedzi na temat utożsamienia adresatów Listu z członkami sekty znanej nam z Qumran ${ }^{63}$. Wskazuje się często na chrześcijan pochodzenia żydowskiego, lecz mocno zhellenizowanych. Wniosek taki wyprowadzają niektórzy autorzy $\mathrm{z}$ treści Listu ${ }^{64}$. Ten jednak wniosek nie jest zadowalający i dlatego można stwierdzić, że z całej dyskusji wynika pozostawanie problemu kwestią otwartą ${ }^{85}$.

W dyskusjach, które zostały powyżej krótko omówione, nie bierze się właściwie pod uwagę tytułu Listu ,,do Hebrajczyków”, który najprawdopodobniej dołączono do tekstu w wieku drugim ${ }^{66}$ i przez swoją ogólność niewiele mówi. A jednak nad tym tytułem trzeba się zastanowić. Jeżeli został nadany, nie stało się to przypadkowo, zwłaszcza, że sam termin hebraios występując trzykrotnie w Nowym Testamencie, zachodzi w Dziejach Apostolskich w kontekście sprawy Szczepanowej. S. Łach przeprowadza analizę terminu „Hebrajczyk” i jego desygnatu ${ }^{67}$. Stwierdza on. że termin ten w Nowym Testamencie oznacza wszystkich Żydów lub tylko tych, którzy mówili po aramejsku. Pierwsze znaczenie, ogólne ma termin zastosowany w Listach Pawłowych (2 Kor 11,22; Flp 3,5), gdzie Paweł podkreśla swoją przynależność do narodu wybranego. Liczniejsze w Nowym Testamencie są zastosowania terminów pochodnych na oznaczenie języka hebrajskiego. Natomiast najbardziej interesuje nas sam termin w Dziejach Apostolskich $(6,1)$.

Gdy wzrosła liczba uczniów w kościele jerozolimskim, na tle rozdawania jałmużny wyłonił się podział na hellenistów i Hebrajczyków. Pierwsi mówili po grecku i byli bardziej liberalni w swych poglądach, drudzy pochodzili z bardziej ciasnych pod względem poglądów Żydów palestyńskich. Dla obsługi przede wszystkim czujących się pokrzywdzonymi hellenistów wybrano Siedmiu, wśród których na pierwszym miejscu wymieniony jest Szczepan. Szczepan, jak świadczy o tym jego imię, podobnie jak — sądząc również po imionach - pozostali z grupy Siedmiu, należał do nawróconych hellenistów i wśród hellenistów, nie tylko nawróconych, podejmował swą działalność, jeżeli wystąpili przeciw niemu niektórzy z synagog Libertynów, Cyrenejczyków i Aleksandryjczyków. Ci jednak przyjęli nieprzejednaną i nietolerancyjną postawę, charakteryzującą raczej Żydów palestyńskich, określonych poprzednio jako Hebrajczycy. W

63 Por. L. Skwarczewski, Starotestamentowy kult ofiarniczy..., s. 96.

64 Por. J. W. Rosłon, Wstęp do Listu do Hebrajczyków, w: Biblia Poznańska, 3 , s. 529 .

${ }_{65}$ Por. J. W. Rosłon, Święty Paweł, w: Wstęp do Nowego Testamentu, praca zbiorowa, Poznań 1969, s. 490.

${ }^{66}$ Por. H. Langkammer, Teologia Nowego Testamentu. Część druga, Wrocław 1984, s. 272.

67 Por. Hebrajczycy $w$ świetle tekstów biblijnych $i$ pozabiblijnych, ekskurs w List do Hebrajczyków, s. $301-310$. 
rozprawie ze Szczepanem Hebrajczycy także musieli przewodzić pod kierunkiem samego arcykapłana prowadzącego śledztwo $(7,1)$.

Jeżeli więc List do Hebrajczyków jest kontynuacją przerwanej Mowy Szczepana, jest skierowany jakby przeciw jego przeciwnikom, których, chó́ niezbyt dokładnie, można nazwać Hebrajczykami. Czy takie było przeświadczenie tradycji nadającej pismu jego tytuł, trudno stwierdzić definitywnie. Nie można także definitywnie takiej możliwości odrzucić. Powiedzieliśmy, że List skierowany jest jakby przeciw. Autor bowiem podejmuje przerwany wątek mowy Szczepana, ale kieruje go do innych adresatów. Jeśli miał do dyspozycji także pismo Pawłowe skierowane do chrześcijan żydowskiego pochodzenia, to całości, do której fragmenty tamtego pisma włączył, nie kieruje już do tych samych adresatów, gdyż zmiana sytuacji politycznej po roku 70 usunęła ich z pola widzenia. Ten hipotetyczny list Pawłowy mógł przyczynić się do nadania całości tytułu „do Hebrajczyków”, ale nie zmienił faktu, że całość pisana jest, podobnie jak Trzecia Ewangelia i Dzieje Apostolskie, do ogółu chrześcijan, których tam reprezentuje dostojny Teofil. Są to chrześcijanie drugiej generacji, którym czasem brakuje wytrwałości, którzy narażeni są na trudności, a także odstępstwo. Przed tym ostatnim List do Hebrajczyków usilnie przestrzega. Sw. Paweł pisał listy do konkretnych kościołów lokalnych, takimi są również Drugi i Trzeci List św. Jana. Pozostałe listy Nowego Testamentu mają bardzo szeroki zakres adresatów i takim najprawdopodobniej jest List do Hebrajczyków. Jego nazwa utworzona na wzór tytułów Listów Pawłowych, może nawiązywać do pierwotnego pisma Pawłowego, albo do przeciwstawienia dwu grup, pomiędzy którymi znalazł siẹ Szczepan, może także być konsekwencją wspomnianego już stwierdzenia Dziejów Apostolskich, że Paweł ma zanieść Ewangelię do pogan, królów i synów Izraela $(9,15)$. Ostatni w Corpus Paulinum List przedstawia wyższość Ewangelii nad dziedzictwem, które było udziałem synów Izraela. Cokolwiek decydowało o nadaniu nazwy, jest ona raczej czymś dołączonym do pisma o charakterze ogólnym. Może więc zbędne jest szukanie szczegółowo określonych adresatów.

Podjęliśmy problematykę autorstwa Listu do Hebrajczyków i nie przedstawiając dokładniej szerokiego wachlarza różnych opinii, wysunęliśmy własną hipotezę. Hipoteza ta podejmuje najstarsze chronologicznie rozwiązanie, podane już przez Klemensa Aleksandryjskiego, ale stara się dać nowy sposób argumentacji. Dostrzegając w św. Łukaszu Autora Listu 
do Hebrajczyków, poszukuje motywów, dla których Łukasz miałby napisać ten List i uczynić to $\mathrm{w}$ imieniu Pawła. Rozważania te prowadzą do zobaczenia w Liście do Hebrajczyków kontynuacji przerwanej Mowy Szczepana, którą św. Łukasz zredagował w siódmym rozdziale Dziejów Apostolskich. Hipoteza o tyle będzie prawdopodobna, na ile zostanie poparta przemawiającymi na jej korzyść argumentami. Dlatego rozpatrzono związki Mowy Szczepana z Listem do Hebrajczyków. Jednym z nich jest zwrócenie szczególnej uwagi na modelowy przybytek, jaki Mojżesz zbudował na pustyni. Na marginesie tych rozważań wyłania się problem czasu powstania Listu, który nie został rozwiązany do końca, ale starano się uzasadnić tezę, że List powstał po roku siedemdziesiątym. To pozwoliło wyrazić $\mathrm{w}$ Liście ważną $\mathrm{z}$ wewnętrznych przesłanek tego Listu naukę - Jezusowym kapłaństwie za pomocą nie stosowanej w innych pismach Nowego Testamentu terminologii. Podkreślenie Łukaszowego zainteresowania ideą kapłaństwa Jezusa prowadzi do ukazania wielu powiązań między pismami św. Łukasza a Listem do Hebrajczyków. Są one umocnieniem wysuniętej hipotezy o autorstwie. Na zakończenie umieszczono kilka, może dosyć luźnych, uwag na temat adresatów Listu, jako że problem ten wiąże się z problemem autorstwa.

List do Hebrajczyków to ważne pod względem doktrynalnym pismo Nowego Testamentu. Będąc z założenia odpowiedzią na zarzut, że Jezus zniszczy świątynię i prawo Mojżesza, List ukazuje doskonałość dzieła Chrystusowego, które jest kontynuacją rzeczywistości starego przymierza, ale przerasta je tak dalece, że wprowadza nowy porządek. W kontekście tego doktrynalnego pouczenia List do Hebrajczyków jest przede wszystkim wezwaniem, aby temu darowi Bożemu odpowiedzieć wiernością, której brakło powołanym do zachowania starego przymierza. W obliczu zniechęcenia, opieszałości i odejść, które zaczęły pojawiać się pod koniec pierwszego wieku, Autor Listu do Hebrajczyków napomina: „Spieszmy się więc wejść...” $(4,11)$ i ukazuje Jezusa arcykapłana, który „nam w wierze przewodzi i ją wydoskonala" $(12,2)$.

DE AUCTORE EPISTOLAE AD HEBRAEOS QUAESTIUNCULAE SELECTAE

\section{Argumentum}

Epistola ad Hebraeos - vera margarita Novi Testamenti - multae quaestiones suscitat. Christiani Epistolam scripturam inspiratam esse tenebant et ad Corpus Paulinum eam adnumerabant, sed ab initio opiniones de non-Paulina manu, quae 
Episolam scripsit, existebant. In decursu temporum multis personis primo saeculo viventibus Epistola adscripta erat. Quaestio difficilis permanet et unanimis consensus impossibilis esse videtur.

Hac in dissertatione sancti Lucae Epistola ad Hebraeos tribuitur, quae opinio veterrima est et a Clemente Alexandrino ac Origene procedit. Capitalis quaestio huius disertationis non auctorem sed genesim Epistolae spectat. Hoc originalitatem conclusionis statuit.

Epistola ad Hebraeos, textus tam spectabilis, non fortuitu ortus est, sed realisatio systematicae tendentiae auctoris est. Quae est ista tendentia? Responsum in aliquot constabilitionibus fundatur. In primis Acta Apostolorum Paulum reum mortis Stephani esse ostendunt. Ergo etiam reus interruptionis Stephani sermonis est. Sermo Stephani, quae in septimo capite Actuum Apostolorum invenitur, inexpleta est, sed iustus etiam post mortem dicit (Hbr 11,4). Sermo inexpleta expletionem tendit. Paulus vero huius expletionis obligationem habuit. Tempore tamer: vitae terrestris a Paulo obligatio haec impleta non fuit, licet brevem epistolam in linqua Hebraica - ut aliqui putant — ad Judaeos tempore praeparationis ad bellum contra Romanos scripserit. Lucas ergo nomine sui Magistri continuationem sermonis Stephani scripsit quae Epistola ad Hebraeos est. Haec hypothesis de genesi Epistolae ad Hebraeos eius auctorem ostendit et eius characterem explicat. Specificae canceptiones Epistolae in ea luce facile interpretari possunt. Sunt enim responsionem ad protestationes Judaeorum contra Stephanum, qui propter destructionem loci sancti et eiectionem Mosaicae legis accusatus est. Responsio, quae in Epistola ad Hebraeos alia situatione facta est, praesertim continuationem oeconomiae salutis ostendit. Jesus, quem Stephanus proclamavit, neque locum sanctum neque legem Sinaitici foederis destruxit, sed ita perfecte adimplevit ut vetus realitas nonnisi umbra novae sit.

Hypothesi demonstratione causa conectiones inter epilogum sermonis Stephani et prologum Epistolae ad Hebraeos investiguntur. In epilogo sermonis et in prologo Epistolae Jesus prophetis anteponitur, Jesus ad dexteram Maiestatis Dei ostenditur et angeli mediatores antiqui foederis appellantur. Prologus Epistolae ad Hebraeos ergo interrupta propiter repentinam montem Stephani themata eius sermonis continuat. Deinde communes conceptiones totius sermonis et totius Epistolae enumerantur. Inter alia magni momenti communis amborum conceptio de peccato et obduratione cordis ut adversatione Spiritui Sancto est. Epistola ad Hebraeos obstante multorum opinione mon in multis quidem locis seid multum de Spiritu Sancto tractatur. Hac in re confer meum articulum Rola Ducha Swiętego wedlug Listu do Hebrajczyków, „Ruch Biblijny i Liturgiczny” 34 (1981), p. 119-129. Ergo in doctrina de Spiritu Sancto Epistola ad Hebraeos ab aliis scriptis sancti Lucae non differt. Stephanus sua in defensione de Moyse et de signo tabernaculi dicit. Eadem themata in Epistola ad Hebraeos inveniuntur. Typologia Moyses - Christus, quae in sermone Stephani velut in nuce invenitur, in Epistola ad Hebraeos magnum progressum ostendit praesertim in capitulo tertio $(3,1-6)$ et duodecimo $(12,18-24)$. Jesus Moysem non condemnat, sed maiorem Moysi kloriam habet, eius nempe opus opus Moysis vere antecedit. Sermo Stephani et Epistola ad Hebraeos tamen legem Sinaiticam ut bonam licet non perfectam ostendunt. Stephanus sua in sermone multum de tabernaculo, quod Moyses in deserto aedificavit, dicit. Thema loci sancti communis sermoni et Epistolae ad Hebraeos est. In utroque textu termini Graeci hieron et naos non inveniuntur. Epistola ad Hebraeos non de templo Hierosolymitano agit sed de typico sanctuario, cuius imago tabernaculum Moysis erat et cuius perfectam realisationem sanctuarium coeleste erit. In hac comprehensione destructio templi in 
Hierosolima a Romanis facta anno septuagesimo cum doctrina Epistolae conectionem non habet. Epistola vero Jesum sacerdotem et summum sacerdotem nominat. Is modus loquendi post annum septuagesimum erat possibilis, ergo Epistola ad Hebraeos tragicam post finem belli Judaici scripta est. Thema Christi sacerdotis in Epistola ad Hebraeos explicata proxima est mente sancti Lucae in Evangelio praesertim Infantiae clare manifestata. Cum aliis communibus conceptionibus Epistole et scriptorum Lucae (Tertium Evangelium et Acta Apostolorum), quae in dissertatione probantur, thema sacerdotii probabilitatem positae hypothesis de Luca ut auctore Epistolae ad Hebraeos confirmat. 